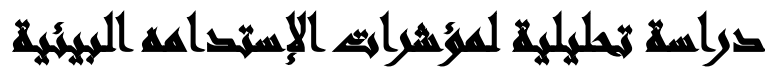 تانل همارايت المهاه
}

[v]

\author{
نشوي يوسف عبد الحافظ
}

قسم الهندسة المعمارية، معهد أكتوبر العالي للهندسة والتكنولوجيا، الجيزة، مصر

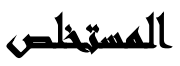

تعد مسارات المشاه من أهم العناصر المؤثره علي العمران سواء بتشكبلها أو تتظيمها

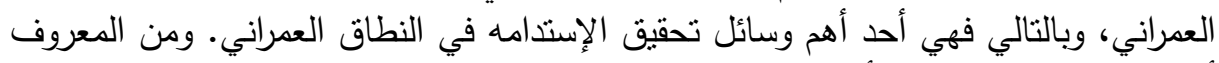

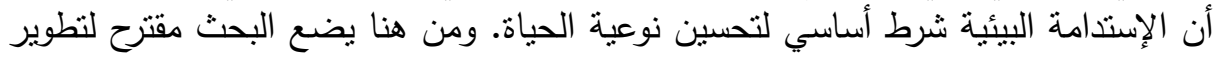

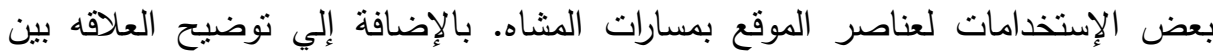

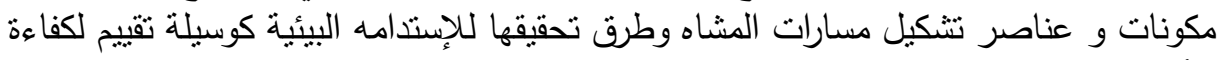

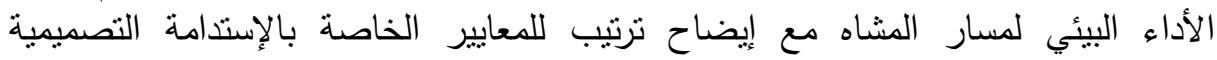

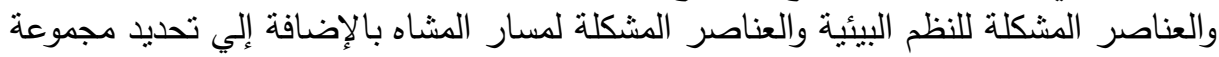

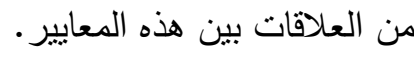
الكلمات المفتاحيه: مؤشرات الإستدامه البيئيه - العناصر المشكلة للنظم البيئية - العناصر

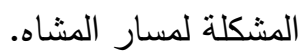

\section{$\Delta$}

تعثبر التتمية المستدامة هي أحد أهم المداخل للتعامل مع المناطق العمرانية المطلوب الحفاظ عليها، ونجد أن شبكات مسارات المشاه من أهم العناصر المؤثره علي العمران

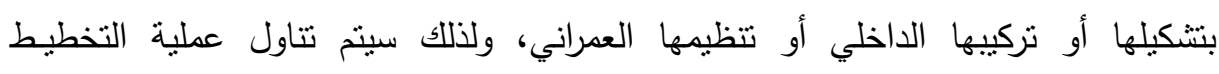
والتصميم البيئي المستدام وذلك لتتميـة بعض الأفكار للمشروعات التتموية العمرانية لإيضاح الدور الهام الذي تقوم به هذه المسارات داخل النظام العمراني. 


\section{إنحالية الهميثر}

تكمن إثكالية البحث في غياب وقصور معظم الدراسات والمخططات العمرانيه الخاصه

بإستخلاص وتطبيق طرق تحقيق الإستدامة البيئيه ووضع قواعد واضحه لها خاصة بمسارات

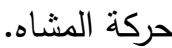

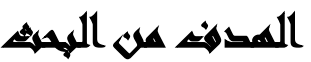

يتمثل هدف البحث في وضع مجموعة أساسيات ومؤشرات لتحسين كفاءة مسارات حركة المشاه فى إطار الإستدامه البيئيه عن طريق مجموعه من المحاور المختلفه، مع وضع أسس يعمل بها عند تصميم مسارات المشاه بالمناطق العمرانيه المختلفه وتحويل مسار المشاه كي يدخل تحت نظام التصميم البيئي.

\section{المنهبيه المتركعه}

إتبع البحث المنهج التوثيقي من خلال الجزء الأول من البحث، ثم يتعرض للمنهج الإستتباطي، الذي من خلاله ينت إختبار المدخل المقترح لإعداد منهجية تحسين مسارات المشاه وطرق قياس النظم البيئية للإستدامه وتقييمها.

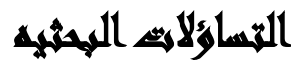

1- ما هي المقومات التي يفترض شمولها في برامج التحسين الخاصده بكفاءة تشكيل مسارات المشاه عن طريق المنظومه المستدامه، وكيف يتم الوصول إلي منهجيه شامله لتحقيق نموذج ملائم لنتكيل هذه المسارات مع وجود طرق لتقييم النظم البيئية كأحد مكونات نظم

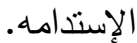
r- ما هي مؤشرات ودلائل تحقيق منهجيه شامله لتحقيق نموذج منهجي لتحسين كفاءة تتكيل مسارات المشاهو طرق تقييم الإستدامه و خاصه النظم البيئية منها ؟ 


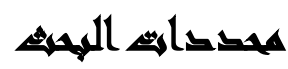

يتشكل الهيكل العام للبحث من خلال إطار تحدده مجموعه من المحدات هي:

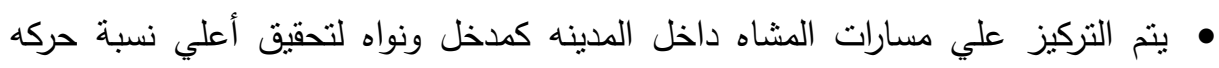

اللمشاه حول الأنثطه المتتوعه داخل الفراغات وكمعبر عن البيئه العمرانيه وخصائصها.

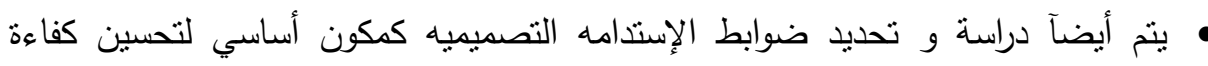
تشكيل مسارات المشاه.

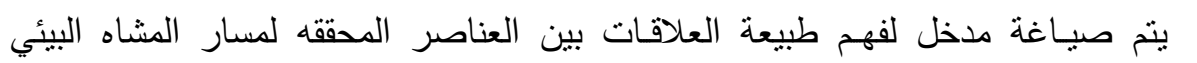

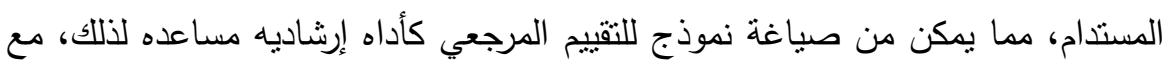

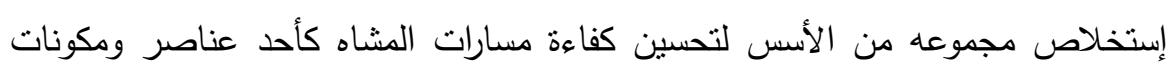
الفراغ العراني، وبذلك يكون قد تم تتاول أدييات موضوع الداسهة من الإطـار العام إلي

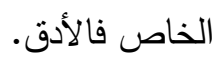

\section{الإخفاهيه المهئهي}

• • إقتراح مدخل لتركيز المعايير المحققه لمسار المشاه البيئي المستدام.

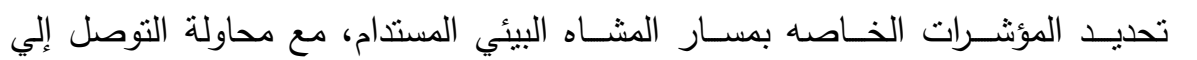

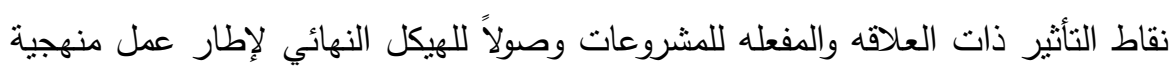
النقييم للنظم البيئية كأحد مكونات نظم الإستدامه.

مسارات المثاه المستدامة: نجد أنه من العوامل الرئيسيه لنحقيق الإستدامه داخل

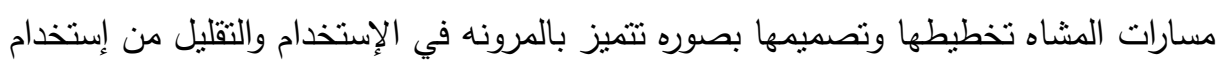

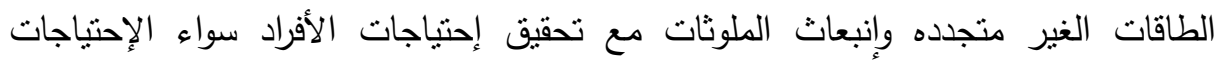

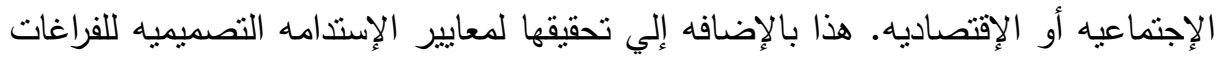

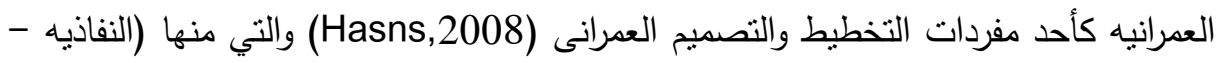

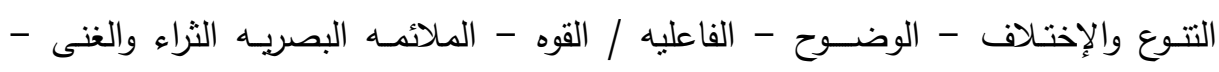

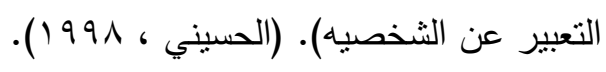


العناصر والخصائص البيئية: تتكون البيئه العمرانيه من مجموعة عناصر تسهم في تكوين الصوره النهائيه لها، وهذه العناصر لا تؤثز فرادي بل مجمعه في تحديد ملامحها. فتختلف البيئه العمرانيه بإختلاف العناصر المشكله لها. (بشندي، ع .. ب)، وتتكون العناصر المشكله لبيئة المدينه من (العناصر المناخيه لبيئة المدينه، علاقة المسار بالمظاهر الطبوغرافيه الموجوده، الفراغات المفتوحه والكتل المبنيه المحيطه بالمسار، الغطاء النباتي وتتسيق الموقع، طبيعة الأسطح العمرانيه، شكل وتوجيه الأسطح العمرانيه، كثافة الحركه

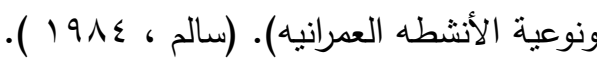

1- العناصر المناخيه لبيئة المدينه: ويمكن إيجاز الخصائص البهانه البيئيه التي تؤثر علي

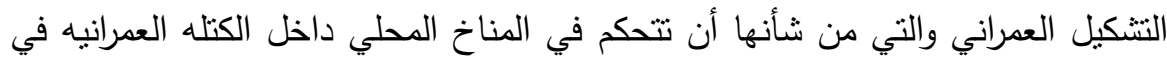
كلاً من: (حركة الثمس والنظام الحراري، حركة الهواء السائدة). وفيما يلي شرح عام لهذه الخصائص كالتالي: أ- بالنسبة لحركة الثمس والنظام العرليدي: هناك العديد من الوسائل التي يمكن من خلالها الحماية من الإشعاع الثمسي وهي: 1 - الإطلال: فعلي المخطط أن يراعي نسبة المسارات المظلله فذلك يؤثز تأثنراً قوياً علي درجة الحراره داخل الفراغات وبالتالي علي حركة الهواء داخل الكتله العمرانيه. ويمكن تصميم واجهات المباني المجاوره بعمل بروزات وكاسرات ووضع هذه المباني بصوره متراصه بجانب بعضها البعض مع توجيهـا بصوره ملائمه لإعتبارات سقوط الأشعه

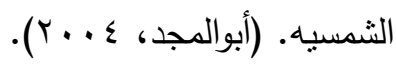

r - مواد الإنشاء: ويتأثز الإشعاع بنوعية المواد المستخدمه في الإنشاء ويختلف تأثثر كل من

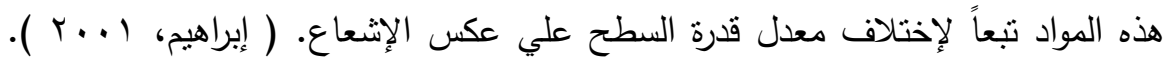

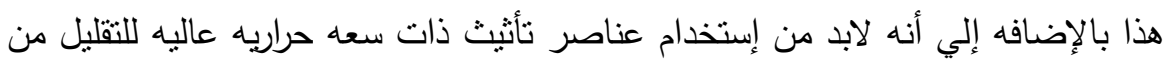

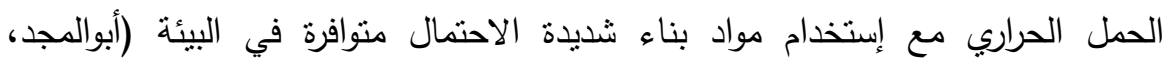
$\cdot(r \cdot \varepsilon$ 


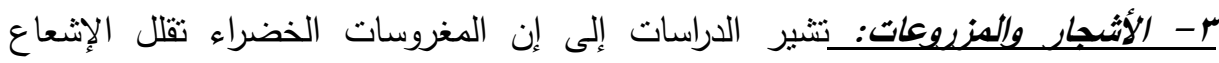

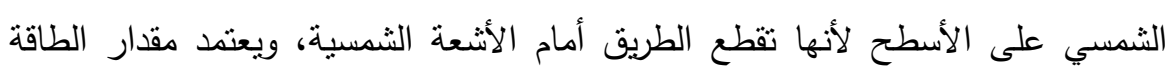

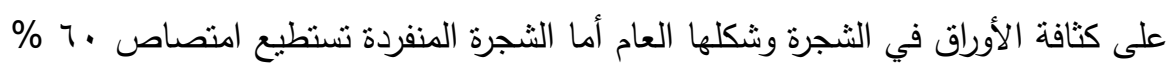
من الأشعة الثمسية. (Peterson, 1996)

צ- النظام الحلري: وفيه يتم محاولة المساعده علي توفير الراحه الحرايه داخل مسار المثناه ويتم ذلك عن طريق (إستخدام العناصر المائية المتحركة - إستخدام الأثجار و معالجات (الأرضيات).

ب- بالنسبة لحركة الهواء السائدة: وفيه يتم صنع مناطق ضغط مرتفع ومناطق ضغط منخفض وذلك بعمل اختلاف في عروض الثوارع والميادين حيث يحدث بالتتابع وجود

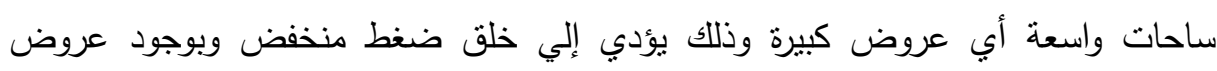

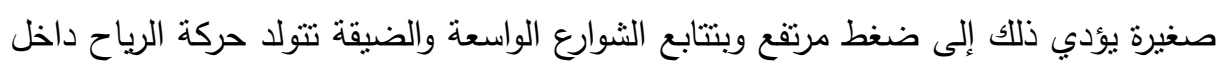
المدن. r- علاقة المسار بالمظاهر الطبوغرافيه المحيطه: ونجد أن إختـلاف مناسيب وميـل

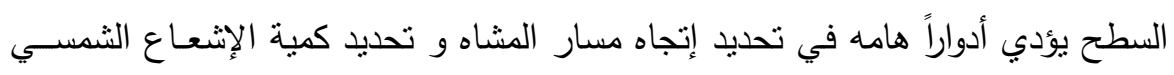
الساقط عليه مع مناطق الإظلال الواقعـه وبالتالي يؤثر في إختبار الموقع.

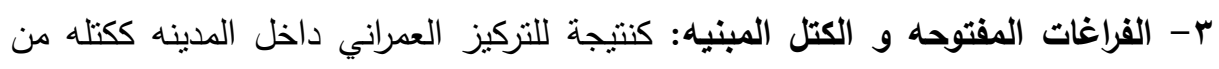

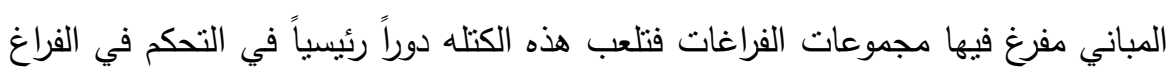

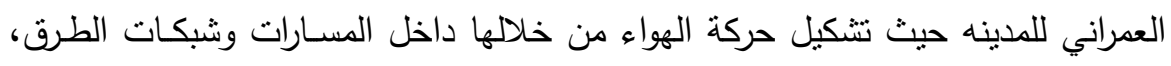
والتغير في درجة حرارة الهواء الملامس للأسطح المختلفه للكتله العمرانيه. ؛ - الغطاء النباتي و تنسيق الموقع: لابد من زيادة المساحات الخضراء والنباتات لأداءها

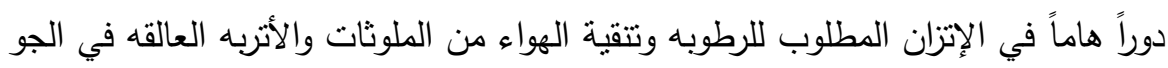
( Jianguo, 2010). ه- طبيعة أسطح المسارات: لابد من مراعاة كلاً من الملمس والإمتصاصيه والإنعكاسيه الخاصه بالمواد المصنوعه منها . 
צ- شكل و توجيه الأسطح العمرانيه: تشكل البيئه المبنيه المحيطه بمسارات المشاه عائقاً أمام حركة الهواء ونظراً لإختلاف توجيه الأسطح المختلفه للكتل المبنيه في المدينه تتغير حركة الهواء عن مسارها الطبيعي. ونتيجه للتغيـر في مسـارات حركة الهواء تزداد المسطحات العمرانيه المعرضه لحركة الهواء وتزداد أيضاً المسطحات المعرضه للسكون

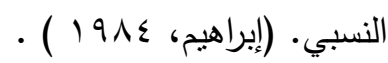

V- كثافة الحركه و نوعية الأنشطه: نتيجة لإرتفاع كثافة الأنشطه من حيث الحركه والنوعيه تزداد كمية الفاقد الحراري الناتج عن هذه الأنشطه فيزداد الحمل الحراري داخل المســارات

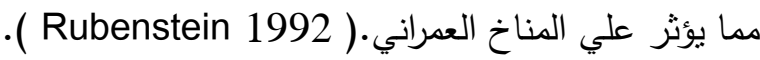
مكونات وعناصر تشكيل مسارات المشاه: يقصد بمكونات مسارات المشاه عناصر التثكيل الخاصده بها والتي تعطيها طابعها و شخصيتها وقد إتفق غالبيـة المخططين

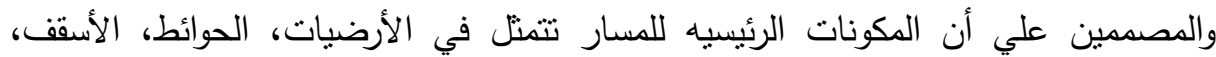
العناصر التكمبليه.

ا-الأرضيـات: وتعني الأرضيات تغطية قاعدة الفراغ بسطح صلب ومنماسك من مواد

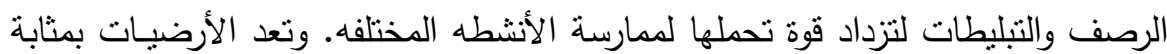
القاعده الأساسيه للأنثطة اليوميه وقاعدة الأثاث بالمسار ( cullen, 1973 ) . r-الحوائط والجدران: والحوائط هي الأسطح الرأسيـه التي تحد فراغ المسـار من الجانبين

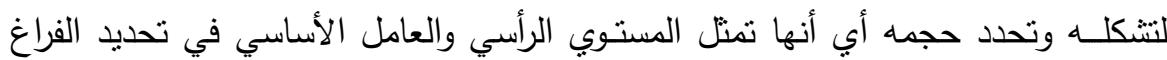
والإحساس بأبعاده فهي مجموعة العناصر المحيطه بالفـراغ سواء أكانت أسوار أو كتل فئل فئل

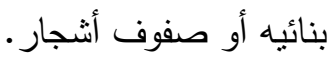
r- الأسـقف: السقف في فراغ المسار هو السماء التي تمتد إلي مالا نهايه ولكن احياناً يحدد

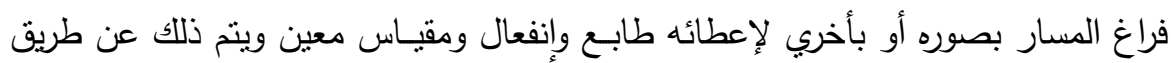
أسقف ثقيلة كالأسقف الخرسانيه أو خفيفة منل البرجـولات والأسقف الخشبيه وأحياناً يتم تسقيف جزء من المسار منل وجود مظلات أمام المحلات التجاريه لخلق فراغ نصف عام 
لجذب الماره، وأحياناً يغطي فراغ المسار بمواد خفيفه منل النباتات التي تنت أفقياً فوق المسار مكونه سقفاً. (فيصل، V. . . Y ).

ع - العناصر التكميليه: وتعتمد العناصر التكميليه علي تحديد شخصية الفراغ وهي نتمل أب أي أني

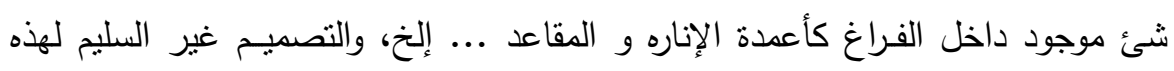

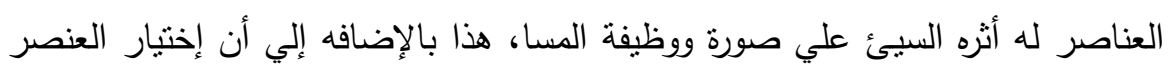

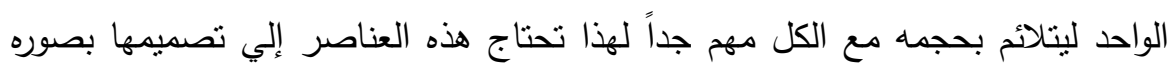

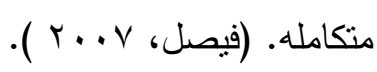

معايير الاستدامه التصميميه للفراغات العمرانيه: وهنا نستعرض معايير الإستدامه التصميميه للفراغات العمرانيه كأحد مفردات التخطيط والتصميم العمرانى ومنها (النفاذيه التتوع والإختـلاف - الوضــوح - الفاعليه - الملائمـهـ البصريـه - الثزاء والغنى - التعبير عن الثخصيه).

• النفاذيه: ويقصد بالنفاذيه هو إمكانات الفراغ العمرانى من حيث الوصول إليه عن طريق عدد من بدائل طرق الإتصال، ونوعية النفاذيه هى التى تتكل استجابة هذا الفراغ

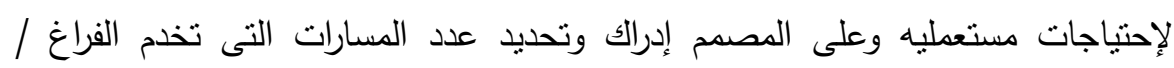

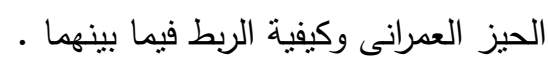

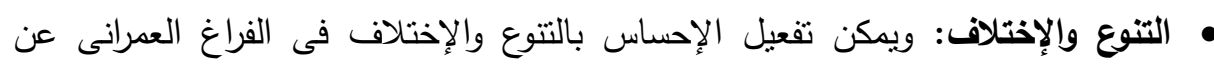

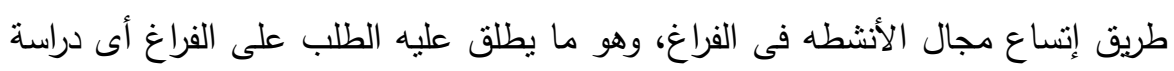
جدوى للأنشطه التى يطرحها الفراغ حسب إمكانياته وموافقتها لرغبات المستعملين.

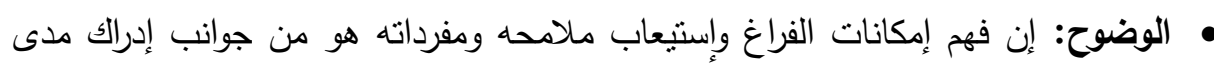
ما يمكن له أن يقدمه للبيئه العمرانيه الموجود بها وبالتالى إستيعاب خصائصده الأخري وهو ما يطلق عليه الوضوح والثفافيه. • الفاعليه: ويمكن زيادة فاعلية الفراغ كأحد عوامل الإستدامه التصميميه له عن طريق زيله زيادة تواجد وظهور المساحات النشطه فى الادوار الأرضيه للمبانى المحيطه بالفراغ العمرانى لئى

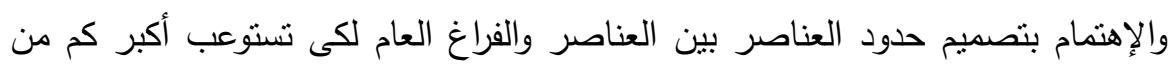


الأنشطه المرغوبه للمستعملين. والتصميم الملائم مناخياً وذلك من حيث عوامل الظلال والتشميس وحركة الرياح وتلائمها مع الأنشطه بالفراغ العام. • الملائمه البصريه: الملائمه البصريه هى ظهور النواحى التصميميه السابقه فى البيئه

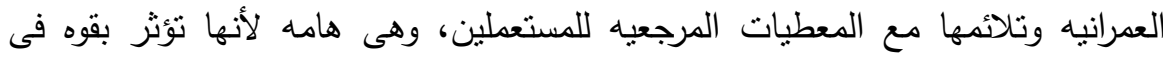
تفسيرات المستعملين تجاه الحيز / النطاق العمرانى الذى يحتويهر. الغنى - ثراء التفاصيل: وهى تلك الخاصيه التى تزيد من تفاعل المستعملين مع بيئتهم، وهى ليست بالضروه خبره مرئيه، ولكن يمكن أن ترتبط بالمشاعر المستولده فى الفراغ كإحساس الحركه، الرائحه، السمع ،اللمس للحصول على الخبره الثعوريه فى الفراغ

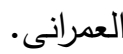
• التعبير عن الثخصيه: فمن الهام ترك مساحة الإختبار والتنخل للمستعملين للتعبير عن شخصيتهم فى بيئتهم المحيطه بهم، وهو السبيل الوحيد لكى يصل المستعمل إلى بيئه عمرانيه تحمل بصمته، ونتائج إختباراته وقيمة ومساحة التتاقص بينه وبينها، وذلك عن ما

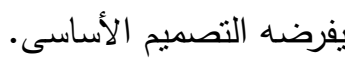


جدول(1): العلاقه بين مكونات و عناصر تشكيل مسارات المشاهو طرق تحقبقها للإستدامه

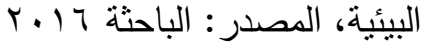

\begin{tabular}{|c|c|c|c|c|c|c|c|c|c|}
\hline \multirow[b]{2}{*}{ الدور الملائم } & \multicolumn{7}{|c|}{ معايير الإستا امه التصميميه للفراغات } & \multirow[b]{2}{*}{ اللنظئلة البنئة } & \multirow[b]{2}{*}{ 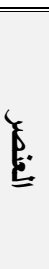 } \\
\hline & .⿹丁龴 & 等 & 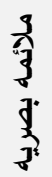 & 可 & 高 & 睃 & 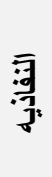 & & \\
\hline \multirow{6}{*}{ 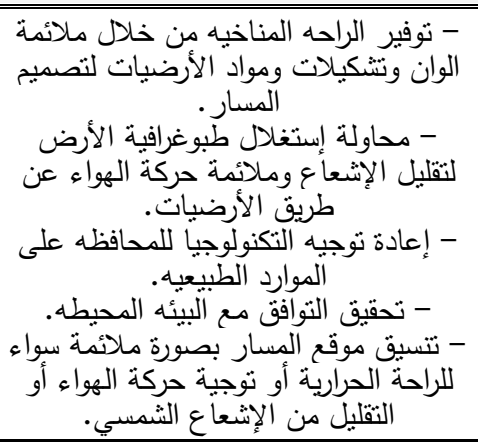 } & & & & & & & & الخصائصة & \\
\hline & & & & & & & & الطبوغرافقية & \\
\hline & & & & & & & & الفراغات & \\
\hline & & & & & & & & التسوقع & \\
\hline & & & & & & & & أسطبحح & \\
\hline & & & & & & & & والتنولة & \\
\hline \multirow{6}{*}{ 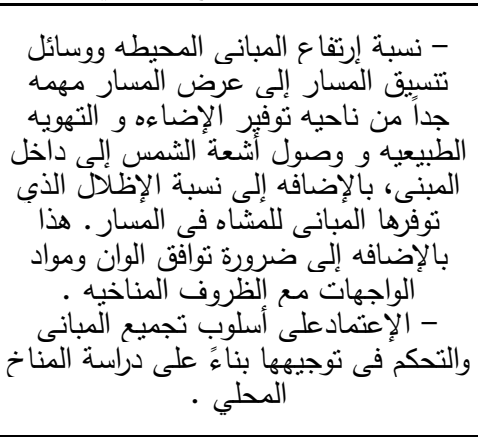 } & & & & & & & & الخصائصة & \multirow{6}{*}{$\underline{E}$} \\
\hline & & & & & & & & الطبوغرافية & \\
\hline & & & & & & & & المفنواغه & \\
\hline & & & & & & & & المواقيق & \\
\hline & & & & & & & & أسطيحة & \\
\hline & & & & & & & & التنكل و & \\
\hline \multirow{6}{*}{ 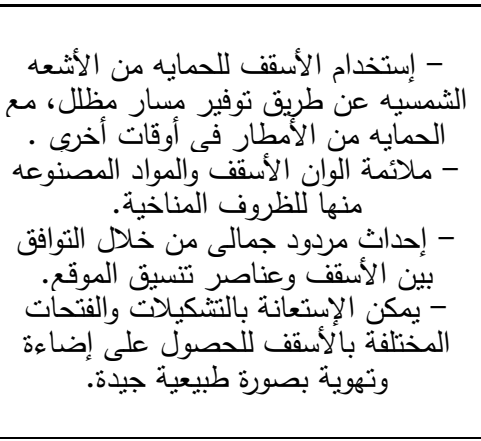 } & & & & & & & & الخنائصة & \\
\hline & & & & & & & & الطبوغراقفية & \\
\hline & & & & & & & & الففتوحات & \\
\hline & & & & & & & & تالتسيق & \\
\hline & & & & & & & & أسطيعة & \\
\hline & & & & & & & & التوجية و & \\
\hline
\end{tabular}

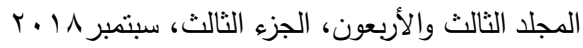


الدراسة التجريبية لعينة المصممين والمستخدمين (المشاة): • المنهج: إعتمد المنهج علي إجراء مقابلات شخصية نصف مهيكلة من خلال إستمارة

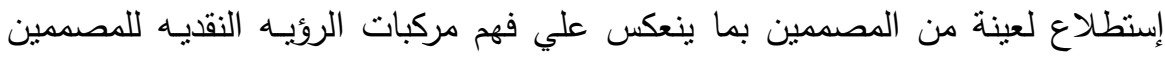
والمستخدمين عن مدي تحقيق الإستدامه البيئية لمسار المشاة . • استمارة الإستطلاع: لقد نم تصميم الإستنيان من خلال طرح وصياغة مجموعه من الإنيان الأسئله من خلال جزئين أساسيين وهما:

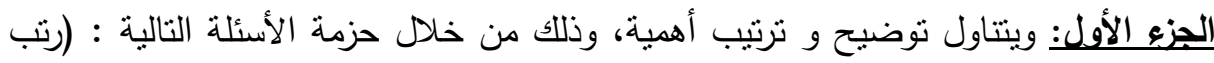

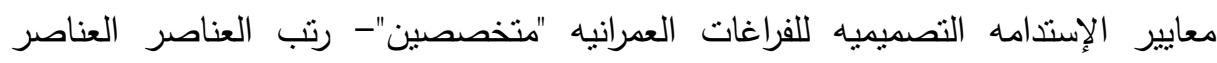
والخصائص البيئية طبقاً لدرجة أهميتها "متخصصين ومستخدمين"- رتب العناصر المكونه

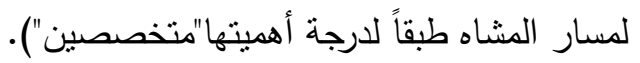

الجزء الثاني: و يتتاول توضيح العلاقات بين كل محور من الثالثه بينهما ببعض من خلال

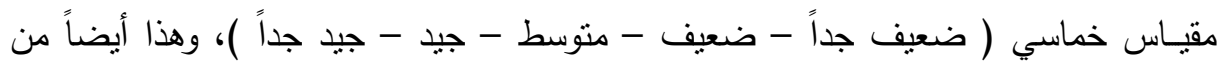
وجهة نظر كلاً منهم بصوره عامه، وذللك من خلال حزمة الأسئلة التالية: (من وجهة نظرك هليط حدد مدي العلاقه بين العناصر والخصائص البيئية ومعايير الإستدامه التصميميه للفراغات العمرانيه، وذللك بوضع علامة ( / ) أسفل الإختيار - من وجهة نظرك حدد مدي العلاقه بين

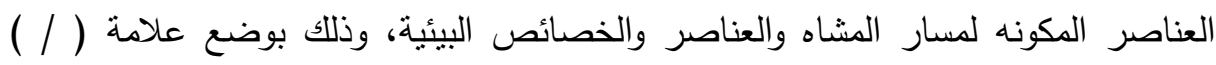
أسفل الإختيار - من وجهة نظرك حدد مدي العلاقه بين معايير الإستدامه التصميميه

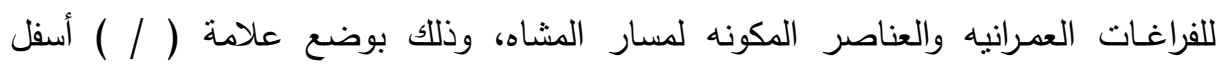

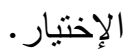
طرح المدخل المقترح - مؤشرات ودلائل: ويشتمل المنهج علي مجموعه من المراحل تصف مجموعة العمليات المنواليه و المتتابعه لجوانب العمل. • الأساليب المتبعه لجمع البيانات: سيتم الإعنماد علي: ( الخرائط المساحيه - الصور الفونوغرافيه - الرفع و التوثيق الميداني و التوثيق المكتبي - استمارات الإسنتيان). 
• مرحلة عرض و تحليل نتائج الإستبيانات: ينتاول هذا الجزء تحليل نتائج الإستبيان بدءاً بوصف العينه البحتيه في كل إستيان و عرض نتائج الإجابات علي الأسئله وتحليلها.

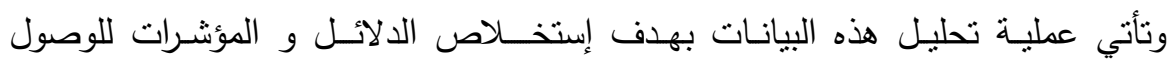
إلي التوصيـات والقرارات.

• الطرق المستخدمه في تحليل البيانات: تم تفريـغ جيـع الإسنبيـانات لكل العينات و جدولتها يدوياً ( جداول تفريغ البيانات ) ثم ثم إدخال المعلومـات إلي الحساسب الألي

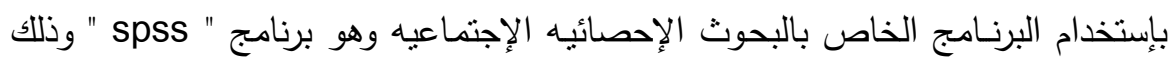

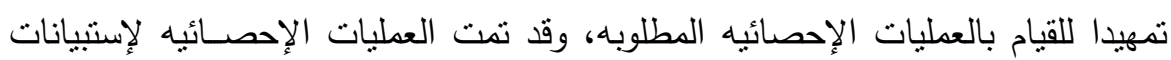

$$
\text { المتخصصين والمشاه كلاً علي حده . المعائ. }
$$

وتنقسم العمليات الإحصائيه التي تم استخدامها إلي مرحلتين أساسيتين وهما:

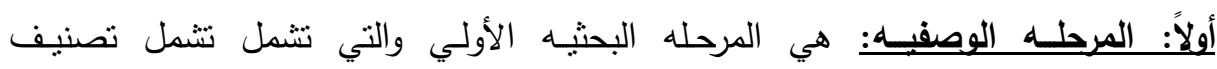
وتوصيف الإستجابات من خلال العمليات الإحصائيه التاليه:

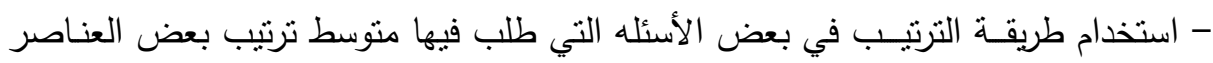
حسب أهميتها.

- المتوسط الحسابي ( أحد مقاييس المتوسطات أو القيم المركزيه )، وقد تم إستخدامه لحساب قيم مختلف متغيرات الإستبيان (ممتاز، V . . Y ).

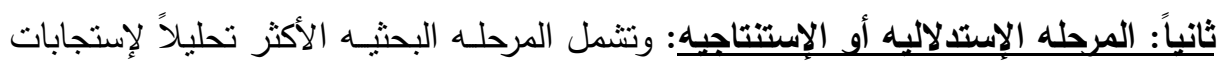
الإستنيانات وذلك من خلال التحليل الإحصائي لبحث العلاقات الإرتباطيه: ويهدف إلي الئي القيـام بالعمليات الإحصائيه لبحث وإستتناج العلاقات بين المتغيرات وإتجاهها، قوة العلاقه

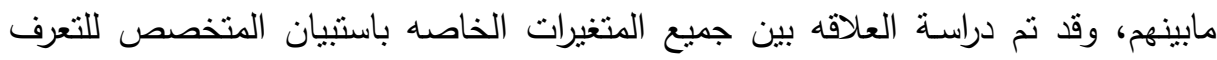

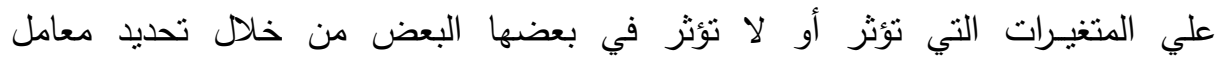

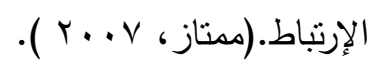
• نتائج تحليل عينة إستبيان المختصين: وتتكون عينة البحث النهائيه من ( • (ه ) من

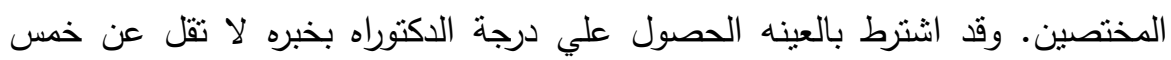
سنوات. وتتقسم نتائج تحليل الإجابات الخاصه بالمتخصصين بنسئه إلي جزئين أساسيين:

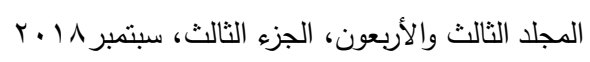


أولاً: مرحلة الإحصاء الوصفيه وتشثل الآتي:

- التحليل الإحصائي الوصفي لمدي أهمية معاييـر الإستدامـهـ التصميميـه . - التحليل الإحصائي الوصفي لمدي أهمية العناصر والخصائص البيئية.

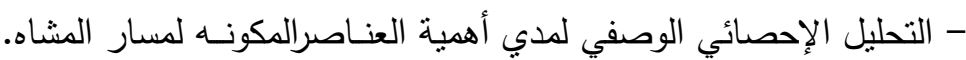

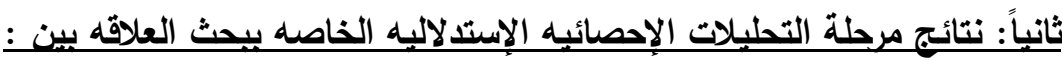
- العناصر والخصائص البيئية ومعايير الإستدامه التصميميه للفراغات العمرانيه. - العناصر المكونه لمسار المشاهوالعناصر والخصائص البيئية . - معسايير الإستدامه التصميميه للفراغات العمرانيه والعناصر المكونه لمسار المشاه . 1 - مرحلة الإحصاء الوصفي: ويعد تحليل الإستمارات كاتت النتيجة كالتالي: أولاً بانسبة لترتيب الأهميات:

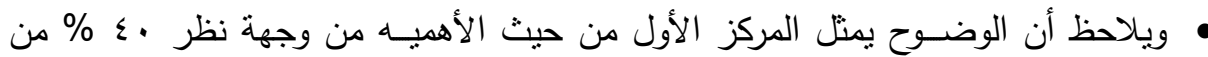

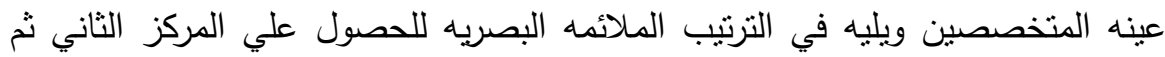
النفاذيه في المركز الثالث والتتوع في المركز الرابـع والفـاعليه في المركز الخـامس ولثخصيـه في المركز السادس وأخيـراً و في المركز السابع ثراء التفاصيل

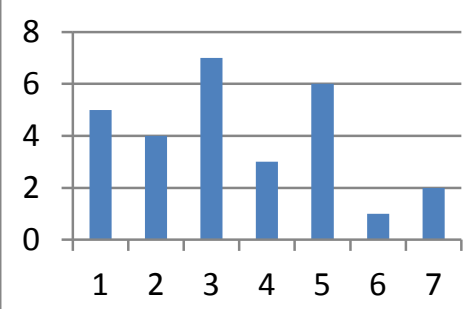

- Series1

شكل(1): ترنيب معايير الإستدامة التصميمية للفراغات العمرانية طبقاً لدرجة أهميتها من وجهة نظر المتخصصين

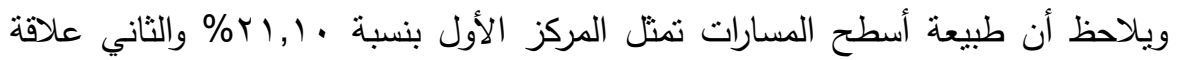
المسار بالمظاهر الطبوغرافية بنسبة • (0,1\% والثالث الفراغات المفتوحة والكتل المبنية

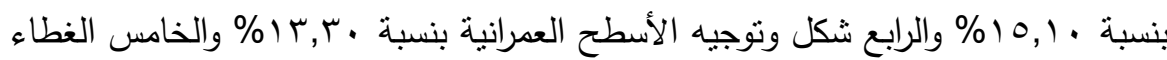




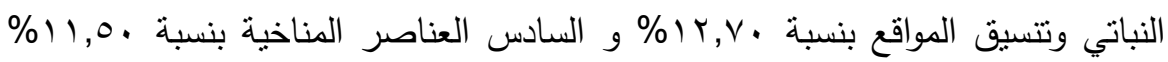

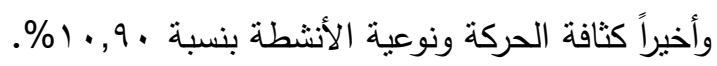

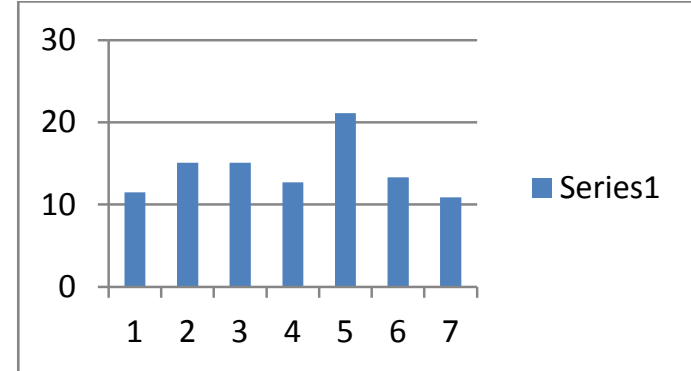

شكل(ץ): ترتيب العناصر والخصائص البيئية طبقاً لدرجة أهميتها من وجهة نظر المتخصصين - - المين

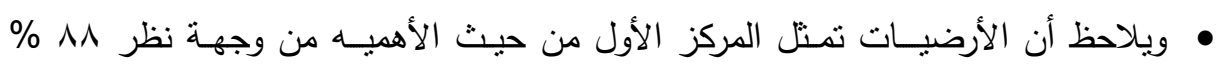

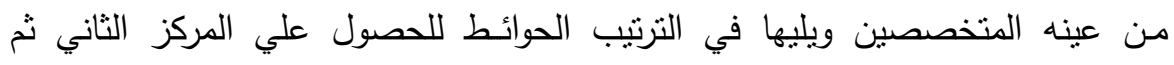
العناصر التكميليه في المركز الثالث

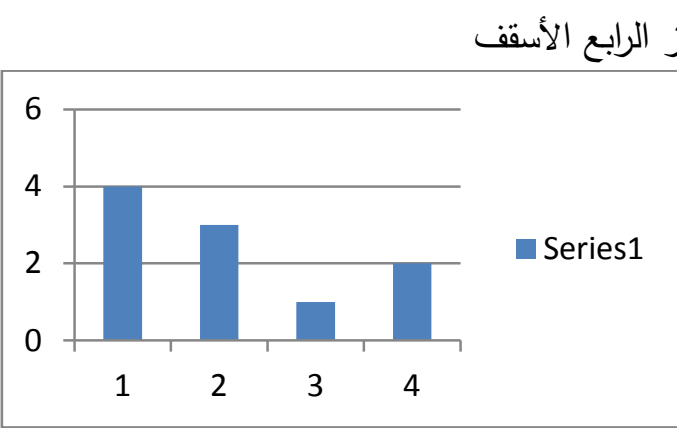

شكل(ץ): ترتيب العناصر المكونة لمسار المشاه طبقاً لدرجة أهميتها من وجهة نظر المتخصصين

ثانياً: بالنسبة لتوضيح متوسط العلاقات:

1- توضيح لهتوسط مدي العلاقـة بين العناصر والخصائص البيئية ومعـايير الإستدامة

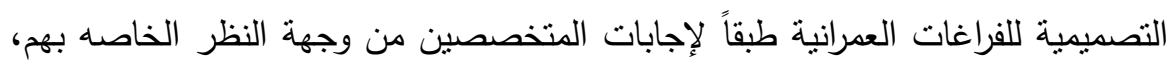

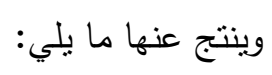


علاقة النفـاذية مع العناصر والخصائص البيئية وفيها تبعاً للترتيب، العلاقه بين النفاذية

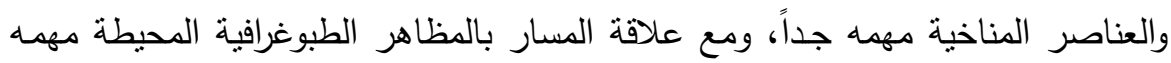

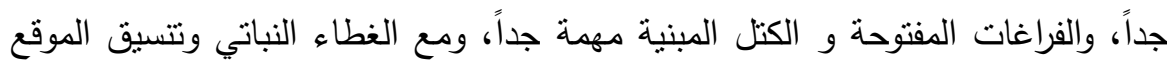
مهمة جداً، ومع طبيعة أسطح المسارات مهمة جدا، و مع شكل وتوجيه الأسطح العمرانية مهمة، ومع كثافة الحركة ونوعية الأنشطة مهمة جداً.

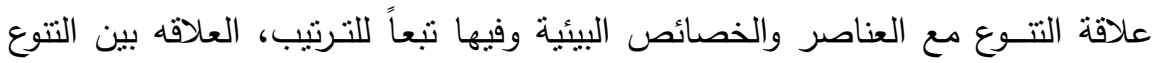
والعناصر المناخية متوسط، ومع علاقة المسار بالمظاهر الطبوغرافية المحيطه مهمة، والفراغات المفتوحة والكتل المبنية مهمة، ومع الغطاء النباتي وتتسيق الموقع مهمة، ومع بـع

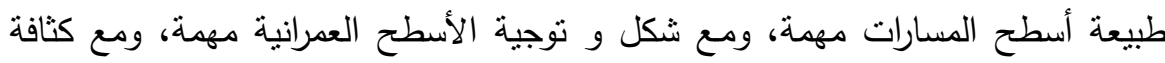
الحركة و نوعية الأنشطه مهمة جداً. علاقة الوضوح مع العناصر والخصائص البيئية وفيها تبعاً للترتيب، العلاقه بين الوضوح والعناصر المناخية متوسط، ومع علاقة المسار بالمظاهر الطبوغرافية المحيطه

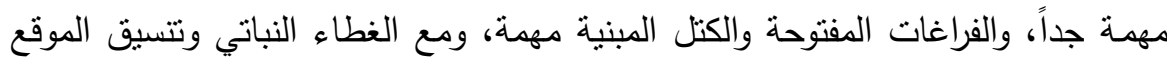

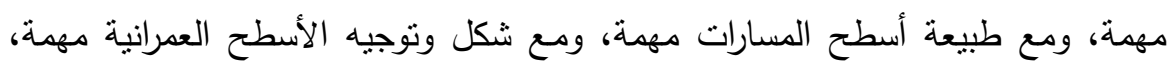
ومع كثافة الحركة و نوعية الأنشطة مهمة جداً. علاقة الفاعلية مع العناصر والخصائص البيئية وفيها تبعاً للترتيب، العلاقه بين الفاعلية والعناصر المناخية متوسط، ومع علاقة المسار بالمظاهر الطبوغرافية المحيطه مهمه جداً، و الفراغات المفتوحة والكتل المبنيه مهمة، و مع الغطاء النباتي وتتسيق الموقع مهمة، وهئ

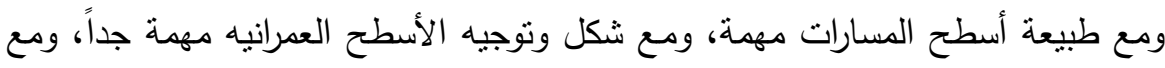
كثافة الحركه ونوعية الأنشطة مهمة جداً.

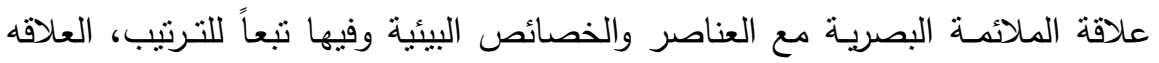
بين الملائكسة البصريـة والعناصر المناخية متوسطة، ومع علاقة المسار بالمظاهر

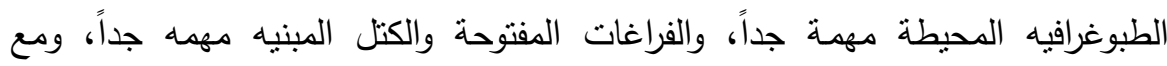


الغطاء النباتي وتتسيق الموقع مهمه جداً، ومع طبيعة أسطح المسارات مهمة، ومع شكل وتوجية الأسطح العمرانية مهمة، ومع كثافة الحركة ونوعية الأنشطة متوسطة.

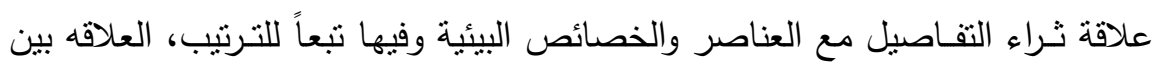
ثُراء التفاصيل والعناصر المناخية منوسطة، ومع علاقة المسار بالمظاهر الطبوغرافيه

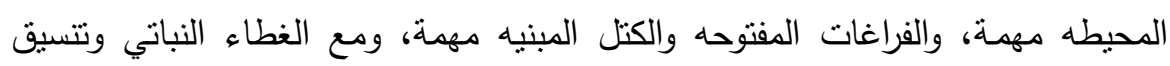
الموقع متوسطة، ومع طبيعة أسطح المسارات مهمة، ومهع شكل وتوجيه الأسطح العمرانيه مهمة، ومع كثافة الحركه ونوعية الأنشطة متوسطة.

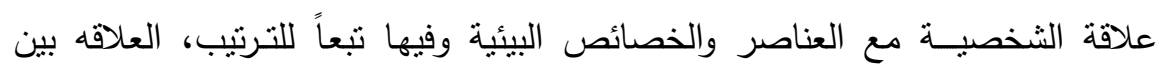
الثخصيــة والعناصر المناخية متوسطة، ومع علاقة المسار بالمظاهر الطبوغرافية

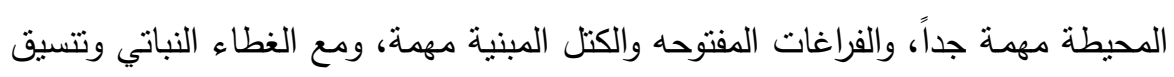
الموقع متوسطة، ومع طبيعة أسطح المسارات متوسطة، ومع شكل وتوجيه الأسطح العمرانيه متوسطة، ومع كثافة الحركة ونوعية الأنشطة متوسطة. r- توضيح لمتوسط مـدي العلاقة بين العناصر المكونة لمسار المشـاة والعناصر

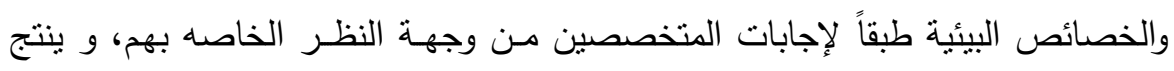
عنها ما يلي: علئ علاقة العناصر المناخية مع العنـاصر المكونة لمسار المشاه وفيها تبعـاً للترتيب،

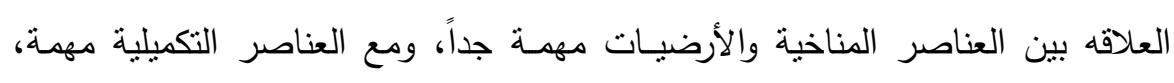
ومع الحوائط مهمة، ومع الأسقف مهمة جداً.

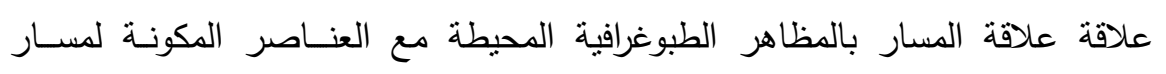
المشاه، وفيها تبعـاً للترتيب، العلاقة بين علاقة المسار بالمظاهر الطبوغرافية المحيطة والأرضيات مهمـة، ومع الحوائط متوسطة، ومع الأسقف مهمة، ومع العناصر التكميلية متوسطة.

علاقة الفراغات المفتوحة والكتل المبنية مع العنـاصر المكونـة لمســار المثــاة، وفيها

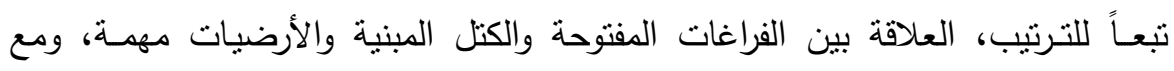
الحوائط مهمة، ومع العناصر التكميلية مهمة، ومع الأسقف مهمة.

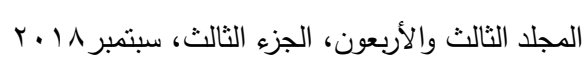


علاقة الغطاء النباتي وتتسيق الموقع مع العنـاصر المكونـة لمســار المشاة، وفيهـا تبعـاً

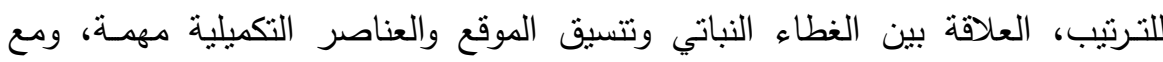
الأرضيات مهمة، ومع الحوائط مهمة، ومع الأسقف منوسطة. علاقة طبيعة أسطح المسارات مع العنـاصر المكونـة لمسـار المشاة، وفيها تبعـاً للترتيب، العلاقه بين طبيعة أسطح المسارات والأرضيات مهمــة جداً، ومع الحوائط مهمة، ومع العناصر التكميلية متوسطة، ومع الأسقف منوسطة.

علاقة شكل وتوجيه الأسطح العمرانيه مع العنـاصر المكونـة لمســار المشاة، وفيهـا تبعـاً للترتيب، العلاقة بين شكل وتوجية الأسطح العمرانية والحوائط متوسطة، ومع الأرضيات مهمة، ومع العناصر التكميلية متوسطة، ومع الأسقف مهمهه.

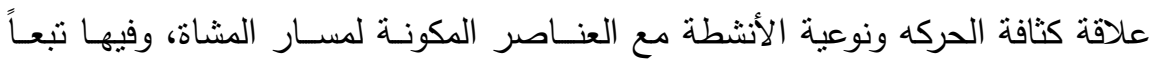

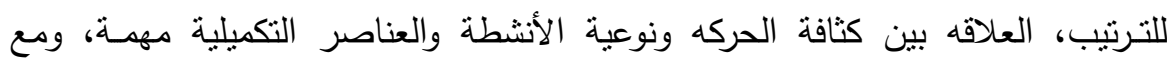
الأرضيات مهمة جداً، ومع الحوائط مهمة، ومع الأسقف مهمة.

r- توضيح لمتوسط مدي العلاقة بين معايير الإستدامة التصميمية للفراغات العمرانية

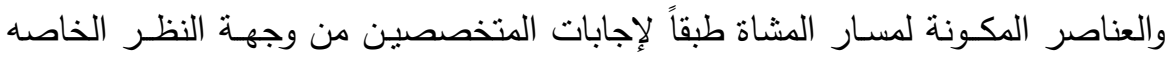

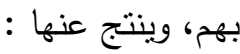

علاقة الأرضيـات مع معايير الإستدامة التصميمية للفراغات العمرانية، وفيها تبعـاً

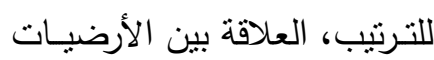

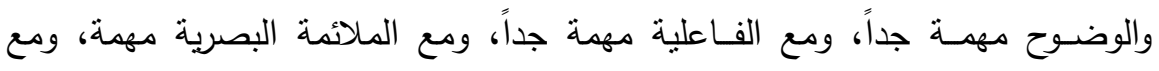

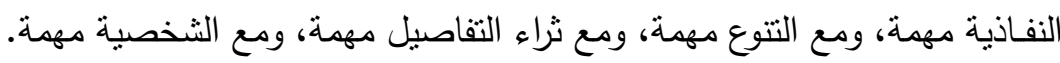

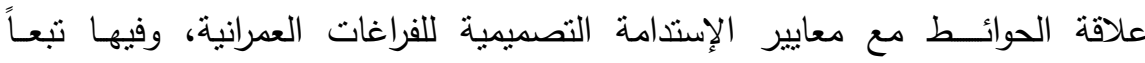
للترتيب، العلاقة بين الحوائط والوضوح مهمة جداً، ومع الملائمة البصريه مهمة جداً، ومع الإنئ

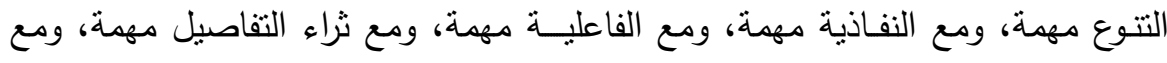

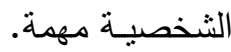


علاقة الأسـقـف مع معايير الإستدامة التصميمية للفراغات العمرانية، وفيها تبعاً للترتيب، العلاقة بين الأسقف والوضوح مهمة، ومع الملائمة البصرية مهمة، ومع الفاعلية منوسطة، مع التتوع منوسطة، ومع ثراء التفاصيل منوسطة، ومع النفاذية متوسطة، ومع

$$
\text { الثخصية متوسطة. }
$$

علاقة العناصر التكميلية مع معايير الإستدامة التصميمية للفراغات العمرانية، وفيها تبعاً

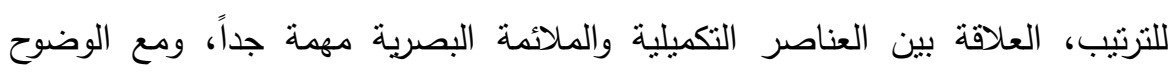

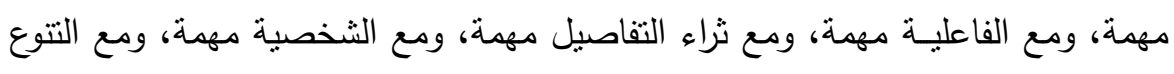
مهمة، ومع النفاذية مهمة. نتائج تحليل عينة استبيان المشاه : وتتكون عينة البحث النهـائيه من ( .9 ) من المشاة ذوي الأسباب و الأهداف المختلفه للسير في المسار فهنالك العديد من الأنشطة التي يتم ممارسته بالمسار منل ( المرور العارض - الإنتقال و السير - التتزه و التسوق و الترفيه اللعب - التجمع - التحدث - الجلوس - الإسترخاء - الإنتظار ).و تتقسم نتائج نحليل الإجابات الخاصة بالمشاة إلي جزئين :

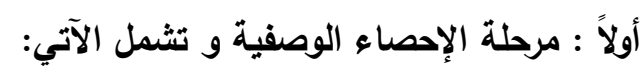

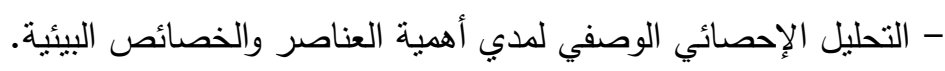
ثانياً : نتائج مرحلة التحليلات الإحصائيه الإستدلالية الخاصة ببحث الإحثية العلاق بين: - العناصر والخصائص البيئية ومعايير الإستدامه التصميميه للفراغات العمرانية. - العناصر المكونه لمسار المشاه والعناصر والخصائص البيئية. 1- مرحلة الإحصاء الوصفي: وبعد تحليل الإستمارات كانت النتيجة كالتالي: ويلاحظ من النائهن

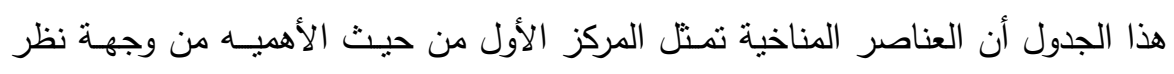
7,9 1\% من عينه المستخدمين ويليها في الترتيب شكل وتوجيه الأسطح العمرانية بنسبة

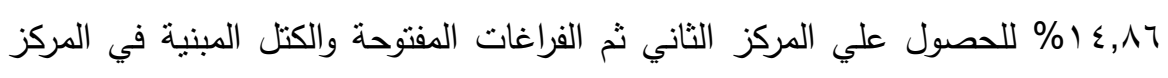
الثالث بنسبة ^,ء إ ثم في المركز الرابع علاقة المسار بالمظاهر الطبوغرافية المحيطة

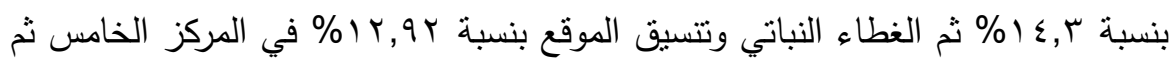




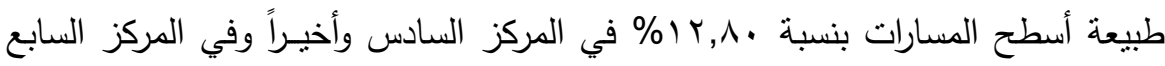

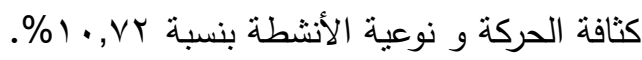

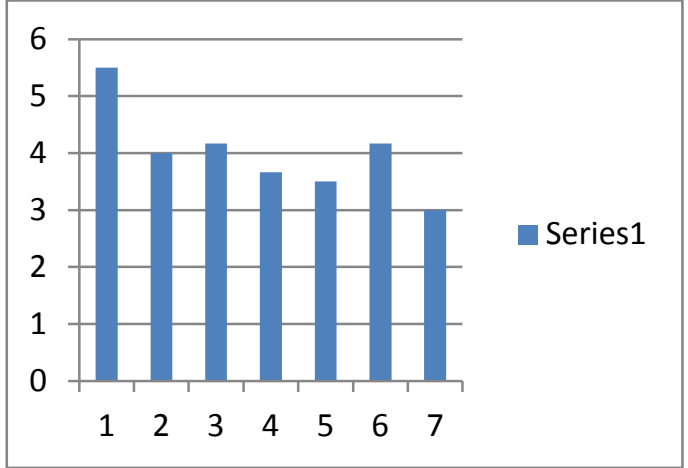

شكل(؟): نرتيب العناصر والخصائص البيئية طبقاً لدرجة أهميتها من وجهة نظر المستخدمين أو المشاة

ثانياً: بالنسبة لتوضيح متوسط العلاقات:

1- توضيح لمتوسط مدي العلاقـة بين العناصر والخصائص البيئية ومعـايير الإستدامة

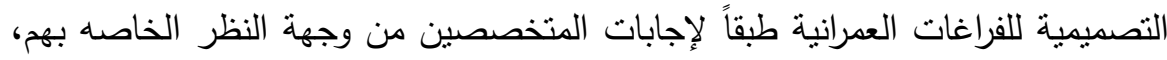
وينتج عنها ما يلي:

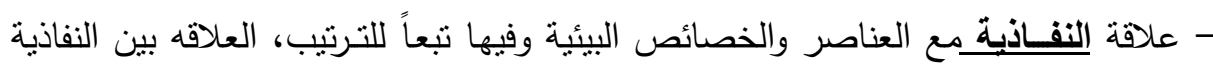

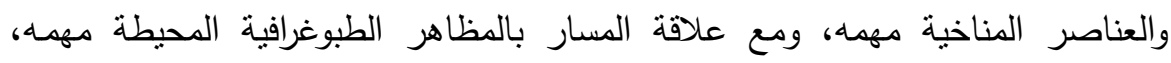

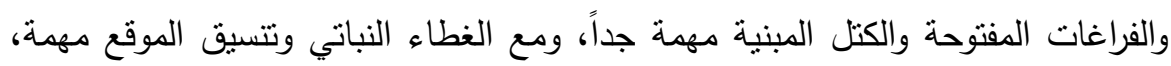

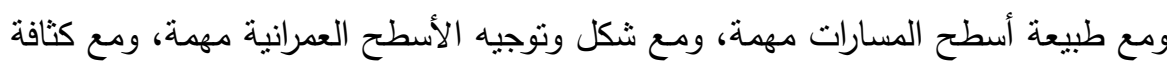
الحركة ونوعية الأنشطة مهمة جداً.

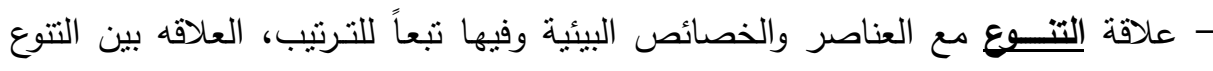

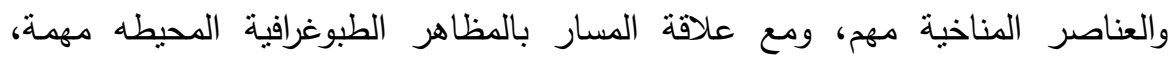

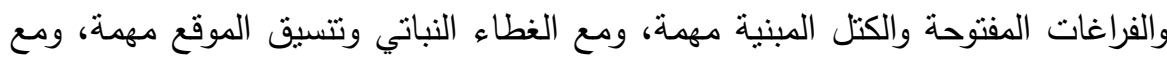

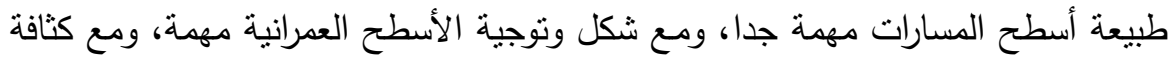
الحركة و نوعية الأنشطه مهمة جداً. 
- علاقة الوضسوح مع العناصر والخصائص البيئية وفيها تبعاً للترتيب، العلاقه بين الوضوح والعناصر المناخية منوسط، ومع علاقة المسار بالمظاهر الطبوغرافية المحيطه مهمة، لهابها

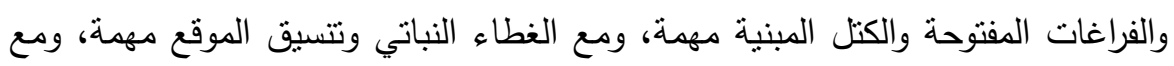

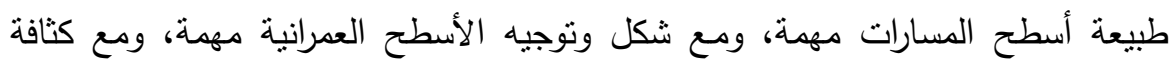
الحركة و نوعية الأنشطة مهمة.

-علاقة الفاعبـة مع العناصر والخصائص البيئية وفيها تبعاً للترتيب، العلاقه بين الفاعلية والعناصر المناخية مهمة، ومع علاقة المسار بالمظاهر الطبوغرافية المحيطه مهمة، و و ولئه

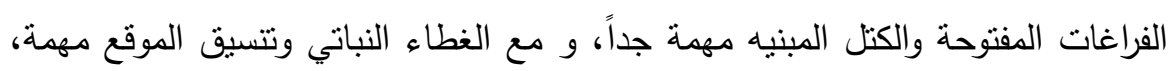

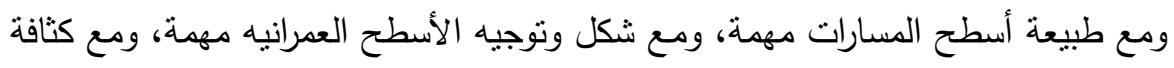
الحركه ونوعية الأنشطة مهمة جداً.

-علاقة الملائمــة البصريـة مع العناصر والخصائص البيئية وفيها تبعاً للترتيب، العلاقه بين

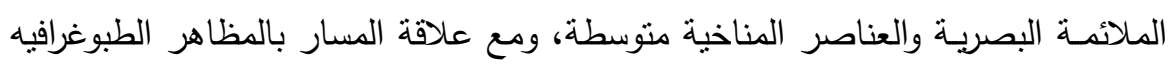

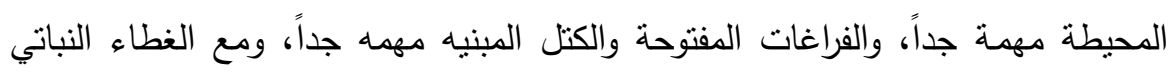
وتتسيق الموقع مهمه جداً، ومع طبيعة أسطح المسارات مهمة، ومع شكل وتوجية الأسطح العمرانية مهمة، ومع كثافة الحركة ونوعية الأنشطة مهمة.

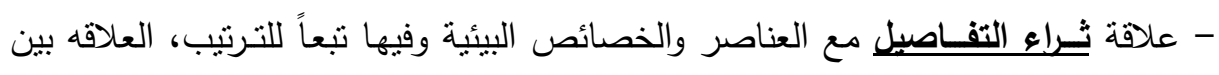
ثراء التفـاصيل والعناصر المناخية مهمة، ومع علاقة المسار بالمظاهر الطبوغرافيه

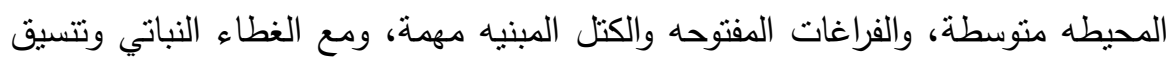
الموقع متوسطة، ومع طبيعة أسطح المسارات مهمة، ومـع شكل وتوجيه الأسطح العمرانيه مهمة، ومع كثافة الحركه ونوعية الأنشطة مهمة.

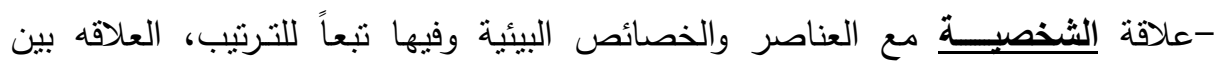

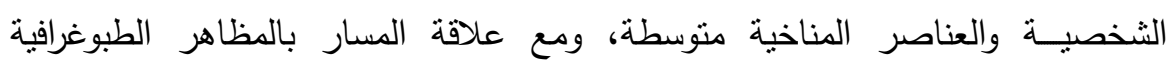

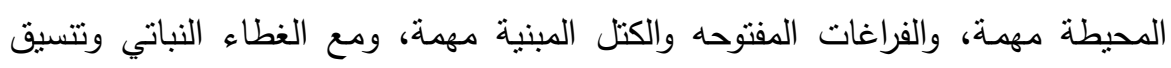
الموقع مهمة، ومع طبيعة أسطح المسارات مهمة، وميع شكل وتوجيه الأسطح العمرانيه مهمة، ومع كثافة الحركة ونوعية الأنشطة مهمة. 
r- توضيح لمتوسط مـدي العلاقة بين العناصر المكونة لمسـار المشـاة والعنـاصر والخصائص البيئية طبقاً لإجابات المتخصصين مسن وجهة النظـر الخاصه بهه، و ينتج عنها ما يلي: عافئ

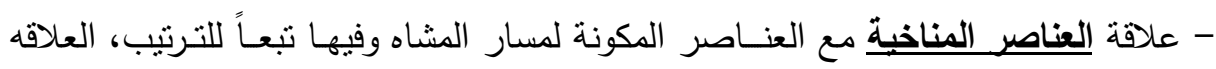

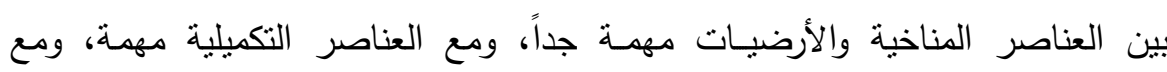
الحوائط مهمة، ومع الأسقف مهمة جداً.

- علاقة علاقة المسار بالمظاهر الطبوغرافية المحيطة مع العنـاصر المكونـة لمسـار المشاه، وفيها تبعـاً للترتيب، العلاقة بين علاقة المسار بالمظاهر الطبوغرافية المحيطة

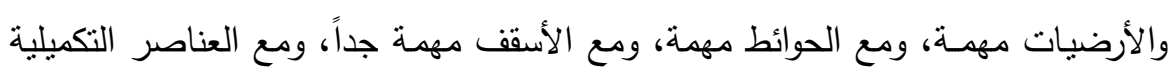
مهم. - علاقة الفراغات المفتوحة والكتل المبنية مع العنـاصر المكونـة لمسـار المشـاة، وفيها

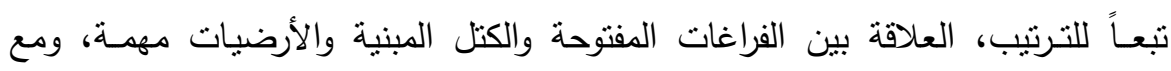

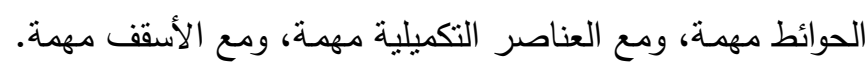

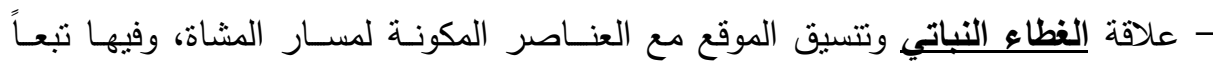

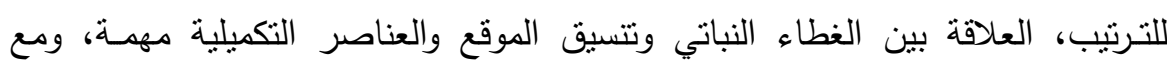
الأرضيات مهمة، ومع الحوائط منوسطة، ومع الأسقف منوسطة.

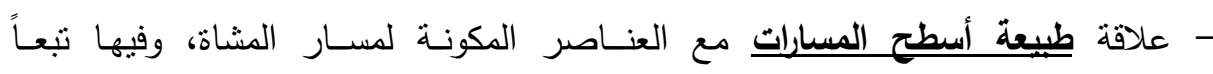

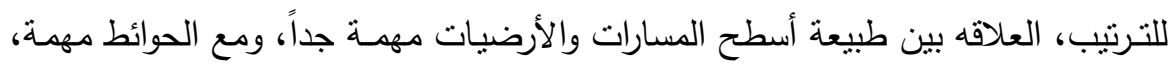
ومع العناصر التكميلية متوسطة، ومع الأسقف منوسطة .

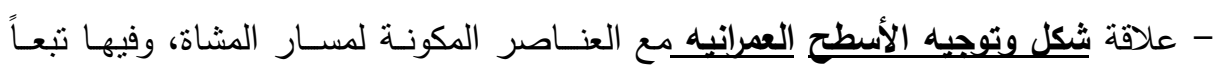

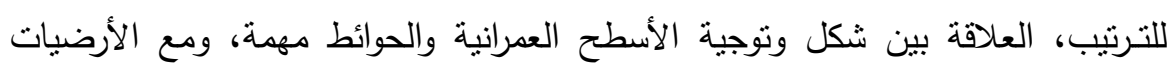
متوسطة، ومع العناصر التكميلية متوسطة، ومع الأسقف مهمهـ. 
- علاقة كثافة الحركه ونوعية الأنشطة مع العنـاصر المكونـة لمسـار الششاة، وفيها تبعـاً للترتيب، العلاقه بين كثافة الحركه ونوعية الأنشطة والعناصر التكميلية مهمـة، ومع لاصعية الأرضيات مهمة جداً، ومع الحوائط مهمة، و مع الأسقف منوسطة.

r- نوضيح لمتوسط مدي العلاقة بين معايير الإستدامة التصميمية للفراغات العمرانية

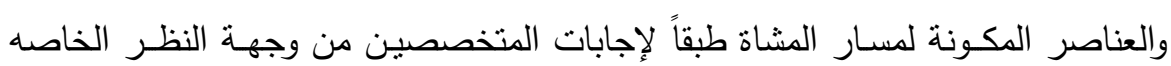
بهم، وينتج عنها:

- علاقة الأرضيـــات مع معايير الإستدامة التصميمية للفراغات العمرانية، وفيها تبعـاً

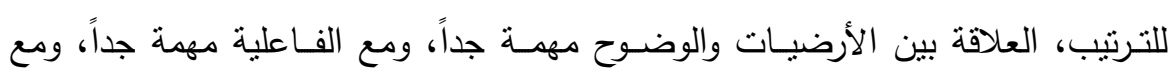

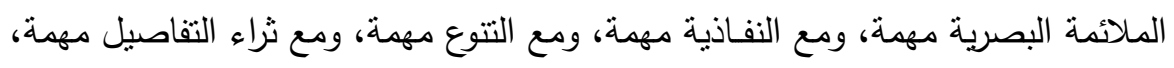
ومع الثخصية مهمة. - علاقة الحوائســــ مع معايير الإستدامة التصميمية للفراغات العمرانية، وفيها تبعـاً

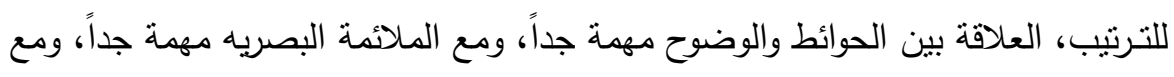

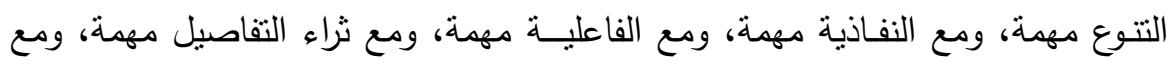
الثخصيبة مهمة.

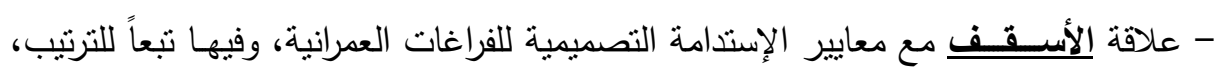
العلاقة بين الأسقف والوضوح مهمة، ومع الملائمة البصرية مهمة، ومع الفاعلية

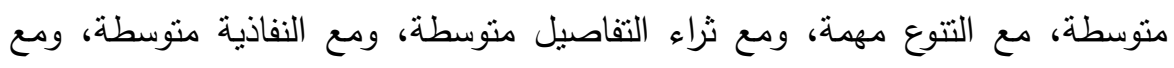
الثخصية متوسطة. - علاقة العناصر التكميلية مع معايير الإستدامة التصميمية للفراغات العمرانية، وفيها تبعاً للترتيب، العلاقة بين العناصر التكميلية والملائمة البصرية مهمة جداً، ومع الوضوح

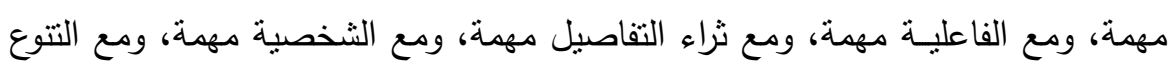

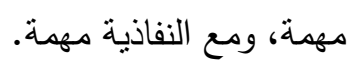


د - نتائج مقارنة كلاً من إستبيان المتخصص والمشاه : جدول(ץ): مدي الإختلافات بين ترتيب العناصر والخصائص البيئية من وجهة نظر المتخصصين و المشاه، المصدر (الباحثة).

\begin{tabular}{|c|c|c|}
\hline ترتيب العنصر & المتخصصين والمشاه & العنصر \\
\hline السادس & المتخصصين & \multirow{2}{*}{ العناصر المناخية } \\
\hline الأول & المشاه & \\
\hline الثانى & المتخصصين & \multirow{2}{*}{ علاقة المسار بالمظطاهر } \\
\hline الرابع & المشاه & \\
\hline الثالث & المتخصصبن & \multirow{2}{*}{ الفراغات المفتوحة والكتل } \\
\hline الثالث & المشاه & \\
\hline الخامس & المتخصصين & \multirow{2}{*}{ الغطاء النباتي وتتسيق الموقع } \\
\hline الخامس & المشاه & \\
\hline الأول & المتخصصين & \multirow{2}{*}{ طبيعة أسطح المسارات } \\
\hline السادس & المشاه & \\
\hline 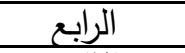 & المتخصصين & \multirow{2}{*}{ شكل وتوجيه الأسطح العمرانيه } \\
\hline الثانى & المشاه & \\
\hline السابع & المتخصصين & \multirow{2}{*}{ كثافة الحركه ونوعية الأنشطة } \\
\hline السابع & المشاه & \\
\hline
\end{tabular}

ومن هذا الجدول نلاحظ التشابة في إختيار نرتيب الأهمية بالنسبة للمتخصصين والمشاه

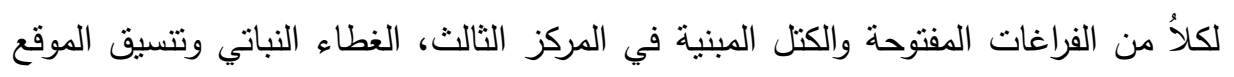
في المركز الخامس وكثافة الحركه ونوعية الأنشطة في المركز السابع 
جدول(ץ): مدي الإختلافات في أهية العلاقه بين العناصر والخصائص البيئية ومعايير الإستدامة

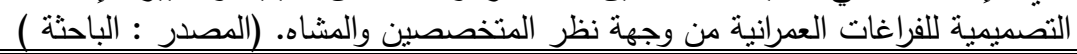

\begin{tabular}{|c|c|c|c|}
\hline الأهمية & المتخصصين والمشاة & معاييز الإستاث/مة التصمرانية & الخصائصن \\
\hline مهمة جدا & المتخصصين & \multirow{2}{*}{ النفــاذيه } & \multirow{14}{*}{ 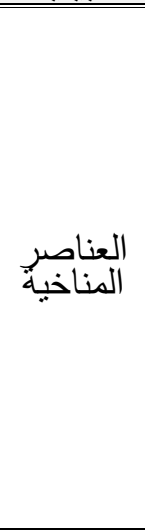 } \\
\hline$\dot{d} 0$ & المشـــاه & & \\
\hline متوسطة & المتخصصنين & \multirow{2}{*}{ التــــوع } & \\
\hline$\ddot{\alpha}$ & المشتـــاه & & \\
\hline متوسطة & المتخصصنين & \multirow{2}{*}{ الوضــوح } & \\
\hline متوسطة & المشّــاه & & \\
\hline متوسطة & المتخصصين & \multirow{2}{*}{ الفــاعليه } & \\
\hline$\ddot{d}$ os & المشنــاه & & \\
\hline متوسطة & المتخصصين & \multirow{2}{*}{ المالائمـــه البصريـــه } & \\
\hline متوسطة & المشتــاهـاه & & \\
\hline متوسطة & المتخصصنين & \multirow{2}{*}{ ثــــاء التفـاصيل } & \\
\hline$\dot{\alpha}$ & المشّـــاه & & \\
\hline متوسطة & المتخصصين & \multirow{2}{*}{ الثخصيـه } & \\
\hline متوسطة & المشــــاه & & \\
\hline مئة جدا & المتخصصين & \multirow{2}{*}{ النفــاذيهـ } & \multirow{14}{*}{ المبالة المسارة } \\
\hline مهو & المشــــاه & & \\
\hline مهرة & المتخصصين & \multirow{2}{*}{ التــــوع } & \\
\hline مهية & المشّــاه & & \\
\hline مهمهة جدا & المتخصصين & \multirow{2}{*}{ الوضـوح } & \\
\hline$\ddot{\alpha}$ & المشُشــاه & & \\
\hline مهرة جدا & المتخصصين & \multirow{2}{*}{ الفــاعليه } & \\
\hline مئه & المشـــاه & & \\
\hline مهرة جدا & المتخصصنين & \multirow{2}{*}{ الملائيـــه البصريــه } & \\
\hline مهمهة جدا & المشّـــاه & & \\
\hline مهمة & المتخصصين & \multirow{2}{*}{ ثــراء التفـاصبل } & \\
\hline متوسطة & المشـــاهـا & & \\
\hline مهوهة جدا & المتخصصين & \multirow{2}{*}{ الثخصيــه } & \\
\hline مهرة & المشـــاه & & \\
\hline مهرة جدا & المتخصصين & \multirow{2}{*}{ النفــاذيه } & \multirow{14}{*}{ 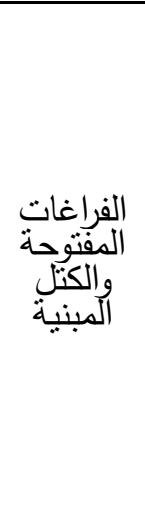 } \\
\hline مهمة جدا & المشـــاه & & \\
\hline مهزمة & المتخصصنين & \multirow{2}{*}{ التتــوع } & \\
\hline مهرم & المشثــاه & & \\
\hline مهرمة & المتخصصين & \multirow{2}{*}{ الوضــوح } & \\
\hline مهرمة & المشتــاه & & \\
\hline dog & المتخصصين & \multirow{2}{*}{ الفــاعليه } & \\
\hline مهوة جدا & المشّـــاه & & \\
\hline مهمة جدا & المتخصصين & \multirow{2}{*}{ المـالئمـــه البصـربــهـ } & \\
\hline مهمة جدا & المشـــاه & & \\
\hline$\ddot{~ م ه ر ة ~}$ & المتخصصين & \multirow{2}{*}{ ثــراء التفــاصيل } & \\
\hline مهرمة & المشّـــاه & & \\
\hline مهرمة & المتخصصين & \multirow{2}{*}{ الثخصيـه } & \\
\hline مهرهـ & المشنــاهـاه & & \\
\hline
\end{tabular}

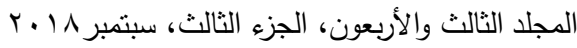


معهد الدراسات والبحوث البيئية - جامعة عين شمس لئه

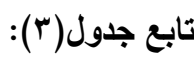

\begin{tabular}{|c|c|c|c|}
\hline الأهمية & المتخصصين والمشاة & معاييليز الأستات العمراتية التصيميميه & الخصائصة البئية \\
\hline مهوة جدا & المتخصصين & \multirow{2}{*}{ النفــاذيه } & \multirow{14}{*}{ النتباتيق } \\
\hline$\dot{\alpha}$ & المشتــاهـا & & \\
\hline مهرة & المتخصصين & \multirow{2}{*}{ التتـــوع } & \\
\hline مهية & المشّــاه & & \\
\hline مهمة & المتخصصين & \multirow{2}{*}{ الوضــوح } & \\
\hline مهمة & المشثــاه & & \\
\hline مهرة & المتخصصين & \multirow{2}{*}{ الفــاعليه } & \\
\hline مهر & المشتـــاهـا & & \\
\hline مهمهة جدا & المتخصصين & \multirow{2}{*}{ الملأئمـــه البصريــه } & \\
\hline مهمة جدا & المشثــاه & & \\
\hline منوسطة & المتخصصين & \multirow{2}{*}{ ثــراء التقـاصيل } & \\
\hline متوسطة & المشّـــاهـاه & & \\
\hline مثوسطة & المنخصصين & \multirow{2}{*}{ الشخصيـه } & \\
\hline مهمة & المشّـــاهـاه & & \\
\hline مهوة جدا & المتخصصين & \multirow{2}{*}{ النفــاذيه } & \multirow{14}{*}{ أمبيبحة } \\
\hline$\dot{\ddot{\alpha}}$ & المشتــاهـاه & & \\
\hline مهرة & المتخصصين & \multirow{2}{*}{ التــــوع } & \\
\hline مهرة جذا & المشثـــاه & & \\
\hline مهرة & المتخصصين & \multirow[b]{2}{*}{ الوضــوح } & \\
\hline مهمة & المشتــاهـاه & & \\
\hline مهزة & المتخصصين & \multirow{2}{*}{ الفــاعليه } & \\
\hline مهرة & المشـــاه & & \\
\hline مهرة & المتخصصين & \multirow{2}{*}{ الملائئـــه البصريـــه } & \\
\hline مهوة & المشّــاه & & \\
\hline مهمة & المتخصصين & \multirow{2}{*}{ ثــراء التفــاصيل } & \\
\hline$\ddot{\alpha}$ & المشتــاهـاه & & \\
\hline متوسطة & المتخصصين & \multirow{2}{*}{ الشخصبـه } & \\
\hline مهر & المشتــاهـاه & & \\
\hline مهرمة & المتخصصين & \multirow{2}{*}{ النفــاذبهـ } & \multirow{14}{*}{ شأتوجليه } \\
\hline مهمة & المشئاهـاه & & \\
\hline مهمة & المتخصصين & \multirow{2}{*}{ التــــوع } & \\
\hline$\ddot{\alpha}$ & المشتــاهـاه & & \\
\hline مهية جدا & المتخصصين & \multirow{2}{*}{ الوضــوح } & \\
\hline$\dot{\alpha}$ & المشتــاهـاه & & \\
\hline مهمة & المتخصصين & \multirow{2}{*}{ الفــاعليه } & \\
\hline مهمة & المشّــــاه & & \\
\hline مهمة & المتخصصين & \multirow{2}{*}{ المـانئمـــه البصريـــه } & \\
\hline مهمة & المشتــاه & & \\
\hline مهوة & المتخصصين & \multirow{2}{*}{ ثــراء التهــاصيل } & \\
\hline مهرة & المشنــاه & & \\
\hline متوسطة & المتخصصين & \multirow{2}{*}{ الثخصيـهـ } & \\
\hline مهرة & المشثـــاه & & \\
\hline
\end{tabular}




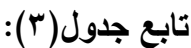

\begin{tabular}{|c|c|c|c|}
\hline الأهمية & المتخصصين والمشاة & معاييزليزألغاتثات العمرانيةيميميه & لخصائية \\
\hline مهمة جدا & المتخصصين & \multirow{2}{*}{ النفــاذيه } & \multirow{13}{*}{ الأنشُعية } \\
\hline مهمة جدا & المشتــاه & & \\
\hline مهمةٌ جدا & المتخصصين & \multirow{2}{*}{ التنـــوع } & \\
\hline مهمة جدا & المشـــاه & & \\
\hline مهوة جدا & المتخصصين & \multirow{2}{*}{ الوضــوح } & \\
\hline مهومة & المشـــاه & & \\
\hline مهومة جدا & المتخصـــين & الفــاعليه & \\
\hline متوسطة & المتخصصين & \multirow{2}{*}{ الملائـــهـ البصريــه } & \\
\hline مهومة مه & المشـــاه & & \\
\hline منوسطة & المتخصصين & \multirow{2}{*}{ ثــراء التفــاصيل } & \\
\hline مهومة & المشتــاه & & \\
\hline متوسطة & المتخصصين & \multirow{2}{*}{ الثخصيـــ } & \\
\hline مهمة & المشتــاه & & \\
\hline
\end{tabular}

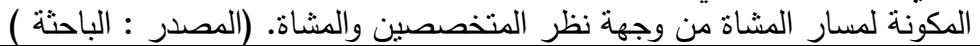

\begin{tabular}{|c|c|c|c|}
\hline الأهمية & المتخصصين والمشاة & المساصر المشائة المكنه & الخصائص البيئية \\
\hline مهمة جدا & المتخصصين & \multirow{2}{*}{ الأرضيات } & \multirow{8}{*}{ العناصر المناخية } \\
\hline مهرم & المشّــاهـاه & & \\
\hline مهُة & المتخصصين & \multirow{2}{*}{ الحوائط } & \\
\hline مهرة & المشثـــاه ". & & \\
\hline مهرةٌة جدا & المتخصصنين & \multirow{2}{*}{ الأسقق } & \\
\hline مهوة جذا & المشــــاهـاه & & \\
\hline مهرة & المتخصصبن & \multirow{2}{*}{ العناصر التكميلية } & \\
\hline مهمة & المشتــاه & & \\
\hline مهرة & المتخصصين & \multirow{2}{*}{ الأرضيات } & \multirow{8}{*}{ بالمظاهر الطية المسارِ المية } \\
\hline مهمهة & المشثــاهـاه & & \\
\hline متوسطة & المتخصصبن & \multirow{2}{*}{ الحوائط } & \\
\hline مهزة & المشـــاهـاه & & \\
\hline مهرة & المتخصصبن & \multirow{2}{*}{ الأسقف } & \\
\hline مهيمة & المشثـــاه & & \\
\hline متوسطة & المتخصصين & \multirow{2}{*}{ العناصر التكميلية } & \\
\hline متوسطة & المشـــــاه ". & & \\
\hline مهمة & المتخصصين & \multirow{2}{*}{ الأرضبات } & \multirow{8}{*}{ الفراغات المفتوحة } \\
\hline مهرة & المشـــاهـاه & & \\
\hline مهرة & المتخصصين & \multirow{2}{*}{ الحوائط } & \\
\hline مهمة & المشتــاهـ & & \\
\hline مهمة & المتخصصين & \multirow{2}{*}{ الأسقف } & \\
\hline مهمة & المشتــاه & & \\
\hline مهمة & المتخصصين & \multirow{2}{*}{ العناصر التكميلية } & \\
\hline مهمة & المشـــاه & & \\
\hline
\end{tabular}

المجلد الثالث والأربعون، الجزء الثالث، سبتمبر 1 ا ـ r 
تابع جدول(؛ ):

\begin{tabular}{|c|c|c|c|}
\hline الأهمية & المتخصصين والمشاة & المسناصر المشارئه & الخصائصليية \\
\hline مهرة & المتخصصين & الأرضيات & \multirow{7}{*}{ والغطاء النباتي } \\
\hline مهرة حدة & المتخصصــاه & \multirow[b]{2}{*}{ الحوائط } & \\
\hline متوسطن & المشـــاه & & \\
\hline متوسطة & المتخصصين & \multirow{2}{*}{ الأسقف } & \\
\hline متوسطة & المشئـاه & & \\
\hline مهم & المتخصصين & \multirow{2}{*}{ العناصر التكميلية } & \\
\hline مهية & المشَــاه & & \\
\hline مهمة جدا & المتخصصين & الأرضيات & \multirow{7}{*}{ طبيعة أسطرات } \\
\hline مهرة & المتخصصين & \multirow{2}{*}{ الحوائط } & \\
\hline مهمة & المشتــاه & & \\
\hline منوسطة & المتخصصين & \multirow{2}{*}{ الأسقف } & \\
\hline متوسطة & المشَــاه & & \\
\hline منتوسطة & المتخصصين & \multirow{2}{*}{ العناصر التكميلية } & \\
\hline منوسطة & المشــاه & & \\
\hline منتوسطة & المتخصصين & \multirow{2}{*}{ الأرضيات } & \multirow{7}{*}{ شكل وتوجيه الأسطرح } \\
\hline متوسطة & المشتــــاه & & \\
\hline مهمة & المشّــاه & الحوائط & \\
\hline مهمة & المتخصصين & \multirow{2}{*}{ الأسقف } & \\
\hline مهرة & المشتــاه & & \\
\hline منوسطة & المتخصصين & \multirow{2}{*}{ العناصر التكميلية } & \\
\hline متوسطة & المشتــاه & & \\
\hline مهمة جدة & المتخصصين & الأرضيات & \multirow{6}{*}{ كثافة الأجريطة ونوعية } \\
\hline مهمية جدا & المتخصصيـاه & \multirow{2}{*}{ الحوائط } & \\
\hline مهمها & المشــاه & & \\
\hline متوسطة & المتخصصين & \multirow{2}{*}{ الأسقف } & \\
\hline متوسطة & المشتــاه & & \\
\hline مهمة & المتخصــــين & العناصر التكميلية & \\
\hline
\end{tabular}


جدول(ه): مدي الإختلافات في أهمية العلاقه بين معايير الإستدامة التصميمية للفراغات العمرانية والعناصر المكونة لمسار المشاة من وجهة نظر المتخصصين والمشاة. (المصدر:

\begin{tabular}{|c|c|c|c|}
\hline الأهمية & المتخصصين & العناصر المشارنة & معاييز الإستأدامة التصميمية \\
\hline مهمة & المتخصصين & \multirow{2}{*}{ الأرضيات } & \multirow{8}{*}{ النفاذية } \\
\hline مهمة & المشـــاه & & \\
\hline مهمة & المتخصصين & \multirow{2}{*}{ الحوائط } & \\
\hline مهمة & المشـــاه & & \\
\hline متوسطة & المتخصصين & \multirow{2}{*}{ الأسقق } & \\
\hline متوسطة & المشـــاه & & \\
\hline مهرة & المتخصصين & \multirow{2}{*}{ العناصر التكميلية } & \\
\hline مهرة & المشـــاه & & \\
\hline مهمة & المتخصصين & \multirow{2}{*}{ الأرضيات } & \multirow{8}{*}{ التنوع } \\
\hline مهرة & المشـــاه & & \\
\hline مهمة & المتخصصين & \multirow{2}{*}{ الحوائط } & \\
\hline مهمة & المشـــاه & & \\
\hline مهمة & المتخصصبين & \multirow{2}{*}{ الأسقف } & \\
\hline مهمة & المشَـاه & & \\
\hline مهمة & المتخصصين & \multirow{2}{*}{ العناصر التكميلية } & \\
\hline مهمة & المشـــاه & & \\
\hline مهمة جدا & المتخصصين & \multirow{2}{*}{ الأرضيات } & \multirow{8}{*}{ الوضوح } \\
\hline مهمة جدا & المشـــاه & & \\
\hline مهية جدا & المتخصصين & \multirow{2}{*}{ الحوائط } & \\
\hline مهمة جدا & المشــــاه & & \\
\hline مهوة & المتخصصين & \multirow{2}{*}{ الأسقف } & \\
\hline مهمة & المشـــاه & & \\
\hline مهمة & المتخصصين & \multirow{2}{*}{ العناصر التكميلية } & \\
\hline مهمة & المشـــاه & & \\
\hline مهمة جدا & المتخصصين & \multirow{2}{*}{ الأرضيات } & \multirow{8}{*}{ الفاعلية } \\
\hline مهوة جدا & المشــــاه & & \\
\hline مهمة & المتخصصين & \multirow{2}{*}{ الحوائط } & \\
\hline مهرة & المشـــاه & & \\
\hline متوسطة & المتخصصين & \multirow{2}{*}{ الأسقق } & \\
\hline متوسطة & المشــــاه & & \\
\hline مهمة & المتخصصين & \multirow{2}{*}{ العناصر التكميلية } & \\
\hline مهرة & المشَـاه & & \\
\hline
\end{tabular}

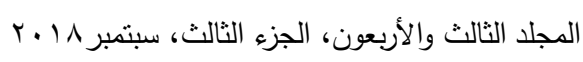


تابع: جدول(ه):

\begin{tabular}{|c|c|c|c|}
\hline الأهمية & المتخصاة" & العناصر المشارنة المشاة & معايير الإستا امة التصميمية \\
\hline مهرة & المتخصصين & \multirow{2}{*}{ الأرضيات } & \multirow{8}{*}{ الملائمة البصرية } \\
\hline مهمة & المشـــاه ". & & \\
\hline مهمة جدا & المتخصصين & \multirow{2}{*}{ الحوائط } & \\
\hline مهمة جدا & المشتــاه ت. & & \\
\hline مهمة & المتخصصين & \multirow{2}{*}{ الأسقق } & \\
\hline مهرة & المشــاه & & \\
\hline مهمة جدا & المتخصصين & \multirow{2}{*}{ العناصر التكميلية } & \\
\hline مهمة جدا & المشـــاه & & \\
\hline مهمة & المتخصصين & \multirow{2}{*}{ الأرضيات } & \multirow{8}{*}{ ثراء التفاصيل } \\
\hline مهرة & المشتـاه & & \\
\hline مهرة & المتخصصبن & \multirow{2}{*}{ الحوائط } & \\
\hline مهرمة مهر & المشـــاه & & \\
\hline متوسطة & المتخصصين & \multirow{2}{*}{ الأسقف } & \\
\hline متوسطة & المشــاه & & \\
\hline مهمة & المتخصصين & \multirow{2}{*}{ العناصر التكميلية } & \\
\hline مهمة & المشـــاه & & \\
\hline مهرة & المتخصصين & \multirow{2}{*}{ الأرضيات } & \multirow{8}{*}{ الثخصية } \\
\hline مهمة & المشتــاه & & \\
\hline مهمة & المتخصصين & \multirow{2}{*}{ الحوائط } & \\
\hline مهمة & المشــاه & & \\
\hline متوسطة & المتخصصين & \multirow{2}{*}{ الأسقف } & \\
\hline متوسطة & المشــاه & & \\
\hline مهرة & المتخصصين & \multirow{2}{*}{ العناصر التكميلية } & \\
\hline مهمة & المشــاه & & \\
\hline
\end{tabular}

ويتضح لنا من هذه الجداول نتائج المقارنة الخاصة بإستنيان المتخصصين والمشاة وذلك هـ من حيث مدي الإختلافات في أهمية العلاقه بين العناصرو الخصائص البيئية ومعايير الإستدامة التصميمية للفراغات العمرانية من وجهة نظر المتخصصين والمشاه، مدي الميه الإختلافات في أهمية العلاقه بين العناصر والخصائص البيئية والعناصر المكونة لمسار المشاة من وجهة نظر المتخصصين والمشاة، مدي الإختلافات في أهمية العلاقه بين معايير

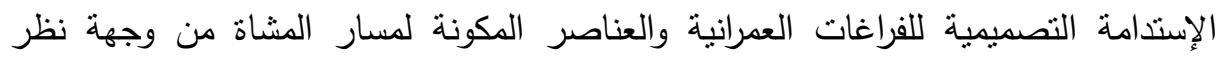
المتخصصين والمشاة. 
إطار عمل منهجية التقييم للنظم البيئية كأحد مكونات نظم الإستدامه بمسارات المشاه: ويتم وضع هيكل إرشادي وفقاً لدلائل عملية تحليل قاعدة البيانات لتقييم النظم والخصائص البيئية كأحد مكونات نظم الإستدامة بمسارات المشاة وتتضمن هذه الجزئية من المنهج المراحل

$$
\text { ا - مرحلة التحليل و صياغة المدخل للنموذج الإرشادي. }
$$

r- المراحل و الطرق المستخدمه بمنهجية تقييم نظم الإستدامه البيئية بمسارات المشاه. r- مرحلة تأسيس الدلائل و المؤشرات المستتتجه من المرحله السابقة. ع - نوفيق المشروع و تطوير النتاج و التتفيذ.

ه- الهيكل النهائي لإطار عمل منهجية التقييم للنظم والخصائص البيئية كأحد مكونات نظم الإستدامة بمسارات المشاه.

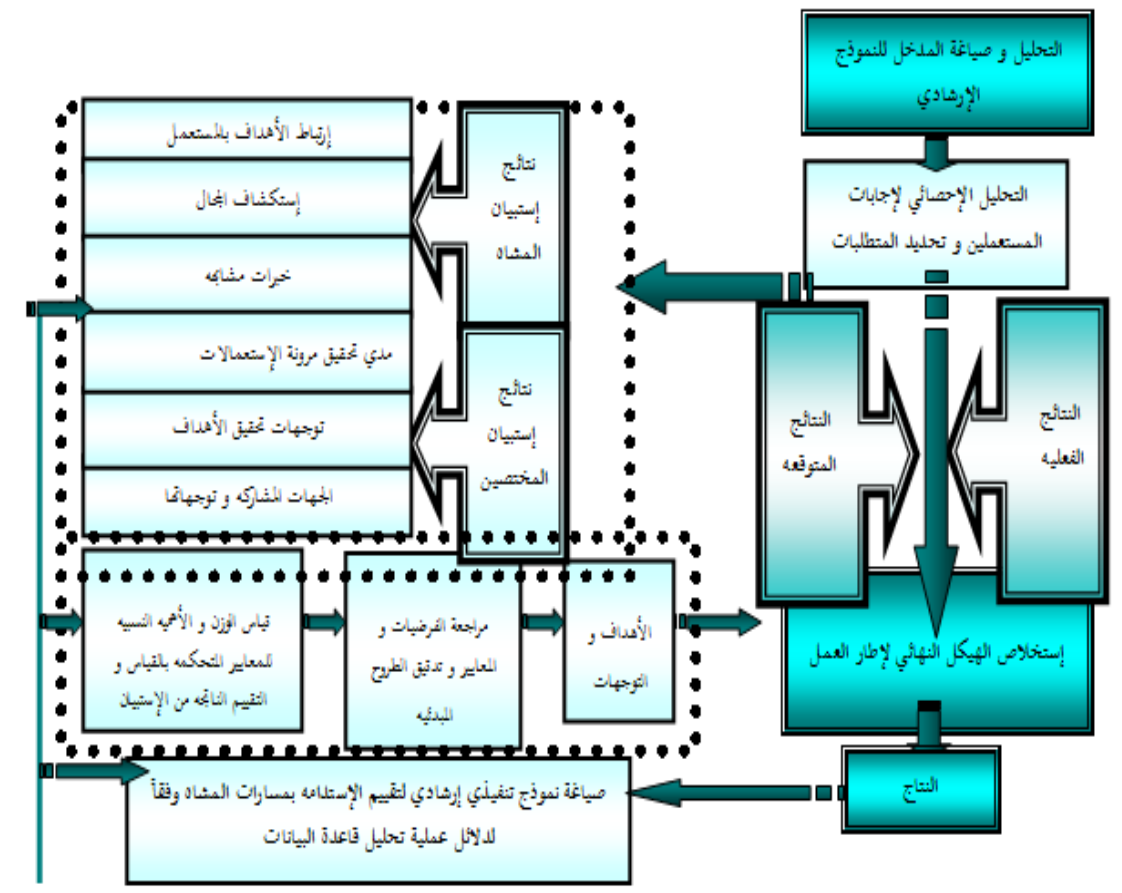

شكل(0): مرحلة التحليل و صياغة المدخل للنموذج الإرشادي، المصدر ( الباحثه ) 
r - مرحلة نموذج التقييم: يمثل استكثاف مدي تحقيق مبادئ ومعايير الإستدامة التصميمية علي مستوي التصميم العمراني أحد الطرق التي تمكن من الروئة الثمولية لنتاج عملية

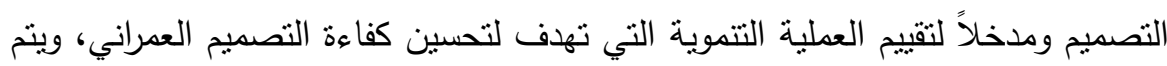
في هذه المرحله توضيح الطرق المستخدمه بمنهجية تقييم نظم الإستدامة البيئية بمسارات

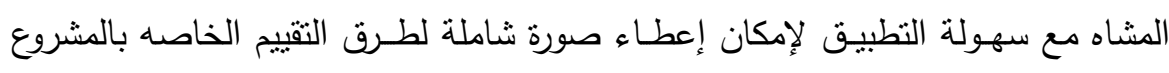
وفق المحاور البيئية. • هدف مرحلة التقييم: تهدف المرحله إلي تقييم المنتج التصميمي لمسار المشاه، وذلك وفقاً لظهور الدلائل الإرشاديه لطروح الإستدامه علي المستوي التصميمي وتدقيق النطبيق علي

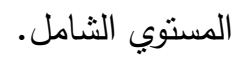
وتختص كل دلاله علي بيان حالة العنصر التي تصفه ومقدار الإيجاب أو السلب في

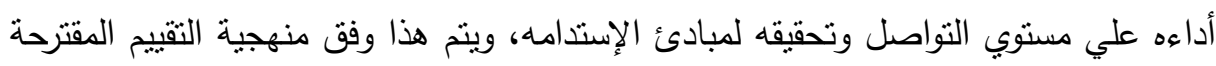

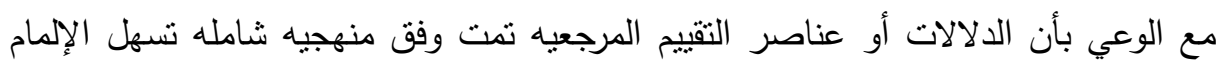

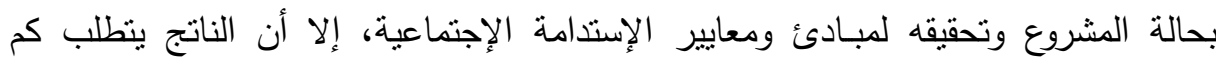

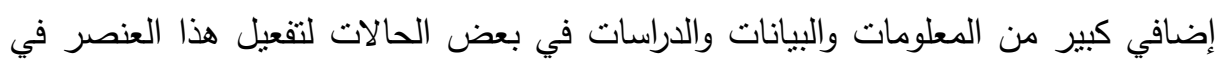

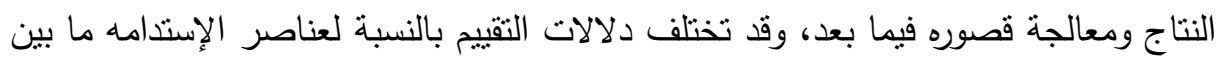

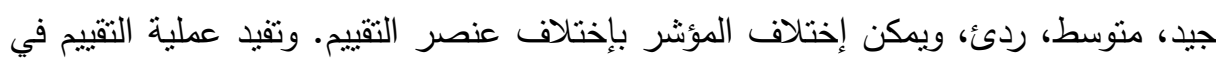
محاولة إيجاد آداه لتقييم النظم البيئية المستدامة بطريقة ولئة مبسطة. 


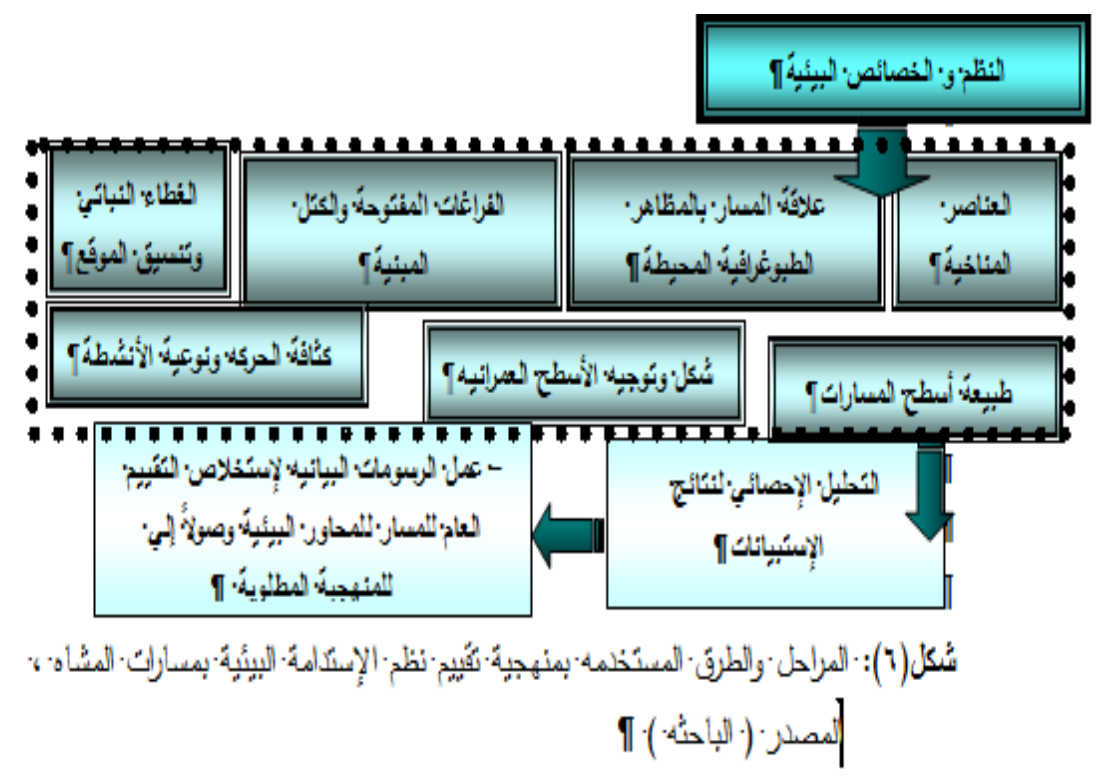

شكل(؟): المراحل والطرق المستخدمه بمنهجية تقييم نظم الإستدامة البيئية بمسارات المشاه،

$$
\text { المصدر ( الباحثة ) }
$$

ويلي هذه المرحله تأسيس الدلائل والمؤشرات المستتجه من المرحله السابقه بحيث تكون

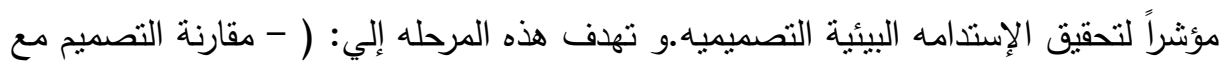
معايير الأداء - معرفة مدي صحة المنتج التصميمي للمسار - المساهمه في المعرفه الكليه حول مدي فاعلية البرنامج ونقاط قوته و ضعفه - الحصول علي تقييم منطقي منهجي لحالة المسار وفقاً لمعايير الإستدامه الإجتماعيه - تحسين التصميم و التتفيذ والإشراف والمتابعه ). 


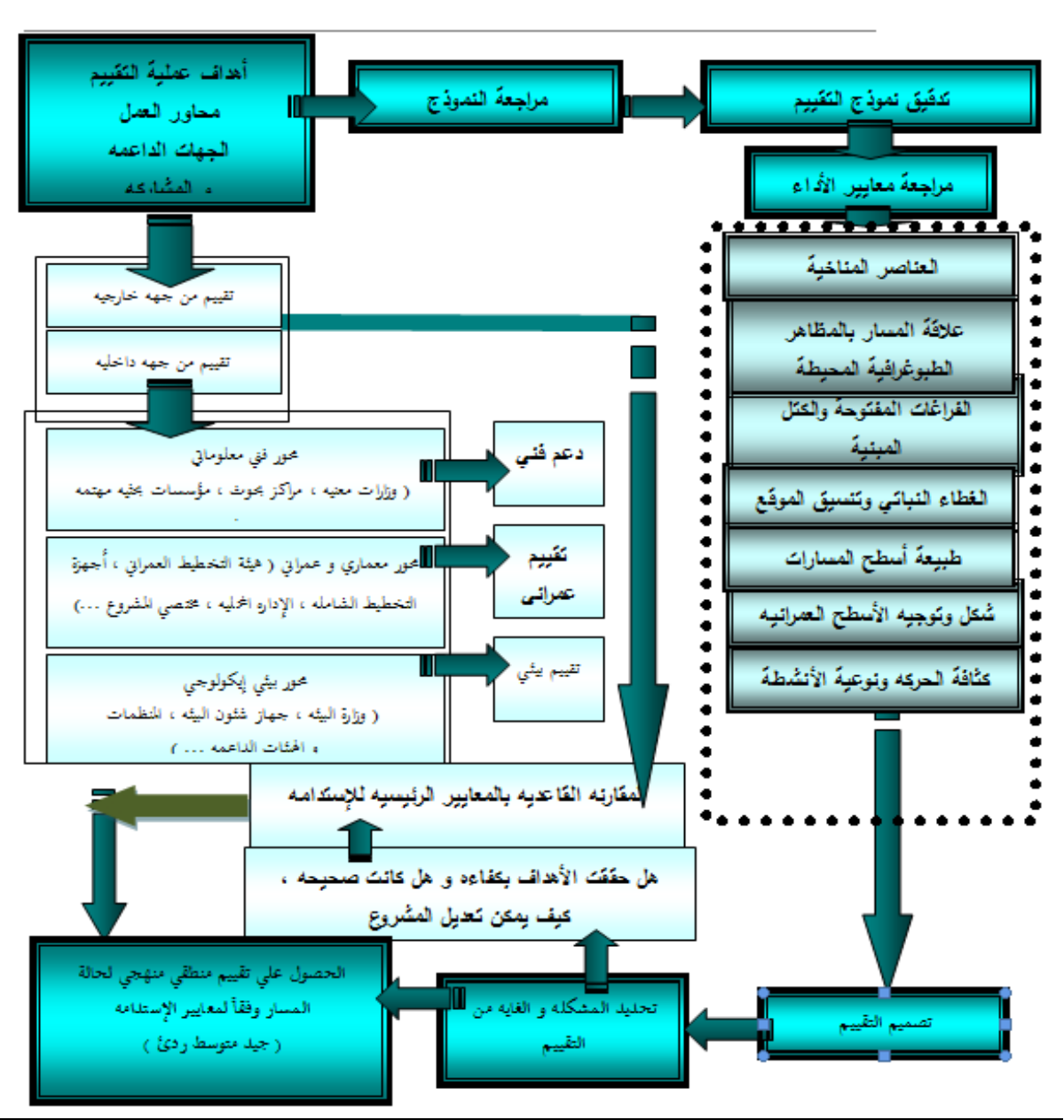

شكل(V): مرحلة تأسيس الدلائل المؤشرات المستتنجة من المرحلة السابقة، المصدر ( الباحثث)

• نموذج التقييم المرجعي: إعتماداً علي نتائج الطرح التطبيقي ( نتائج الإستنيانات الخاصه

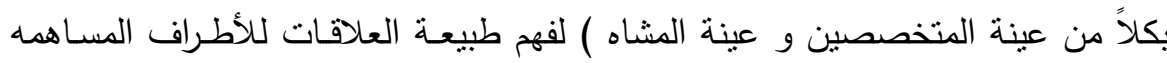
لتحقيق الإستدامه البيئية بمسارات المشاه ( العناصر والخصائص البيئية - معايير الإستدامه التصميميه للفراغات العمرانيه - العناصر المكونه لمسار المشاه ) بصوره تسمح بالتوصل إلي البنيات الأساسيه الغير مباشره لهذه العلاقه نم وضع مدخل للتقييم 
المرجعي كوسيله للتوضيح بين هذه الأطراف و الربط بينهم و القدره علي رؤية هذه الأبعاد

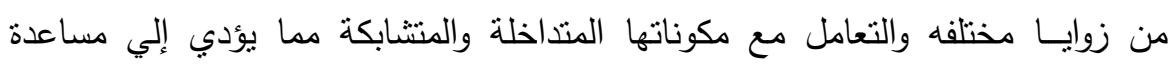
المتخصص في صياغة بيئه متميزه واضحسة المعالم لها تفاعل واعي وإيجابي لتحقيق الإستدامة البيئية و يتم ذلك عن طريق رصد العلاقات المتداخله بين أطراف المنظومه

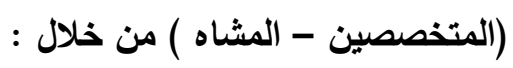

- العلاقه بين العناصر المكونه للنظم الإجتماعيه و معايير الإستدامه التصميميه للفراغات

$$
\text { العمرانيه (عن طريق أهمية وترتيب العناصر كلاً منها مع الآخر ) . }
$$

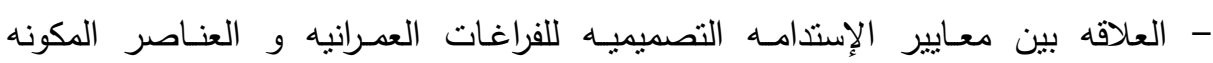

$$
\text { لمسارالمشاه. }
$$

- العلاقه بين العناصر المكونه للنظم الإجتماعيه و العناصر المكونه لمسـارالمشـاه.

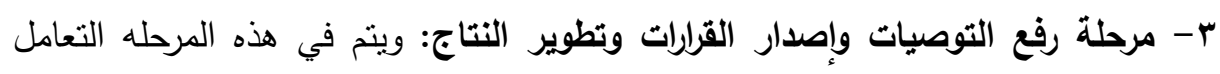

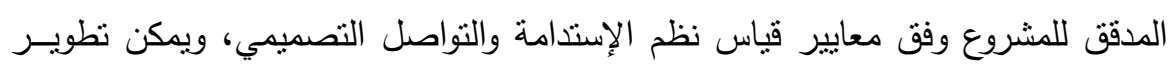
المسار من خلال مجموعه من المقترحات لتحسين كفاءة مسار المشاه والتي من أهمها: - عرض المشروع و تطويره بمعالجة أوجه القصور وتكامل عناصر الإستدامة به من خلاد لهاه المعايير التصميميه الخاصه به - حفز جهود التطبيق و تدقيق التكاليف المرتبطه.

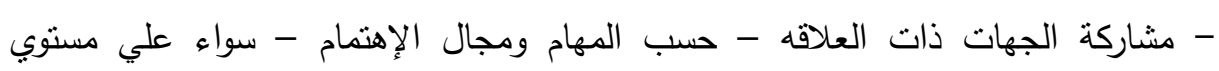
المستخـدم أو المصمم أو المتخصص أو الجهات ذات العلاقة. 


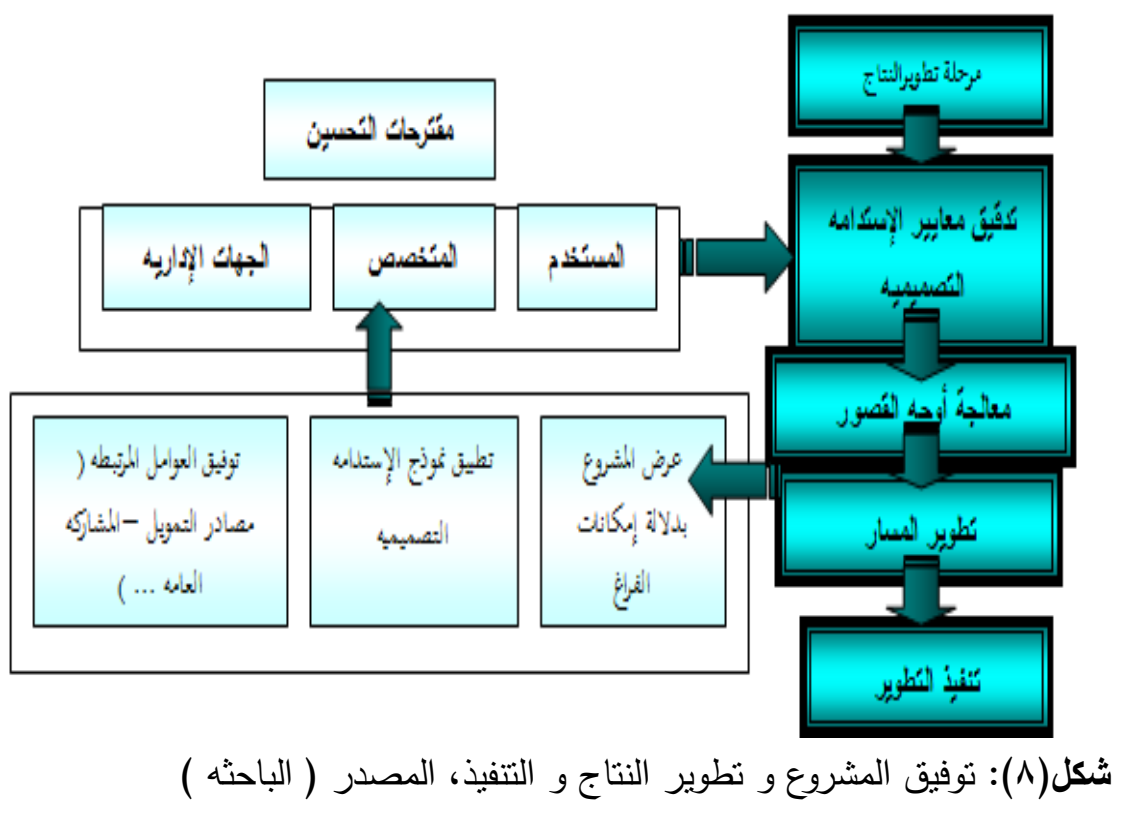

ع - صياغة منهجية تقييم النظم البيئية كأحد مكونات النظم الخاصه بالإستدامه داخل

مسارات المشاه: ومن ذلك يمكن صياغة منهجية نقييم النظم البيئية كأحد مكونات النظم الخاصه بالإستدامه داخل مسارات الششاه وذلك بهدف التوصل لتحقيق أفضل النتائج

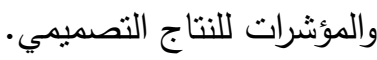

ومن خلال استعراض مراحل العمل و مداخل التعامل مع المقترح المنهي يمكن التعامل مع عملية القياس والتقييم للإستدامه البيئية علي صعيد المشروعات القائمه والإستفاده منها علي مستوي ما قبل التطبيق. ويمتاز هذا المنهج بمرونـة مدخلاته وتعدد مستويـات التقيبم به تبعاُ لأهميتها و وحداتها

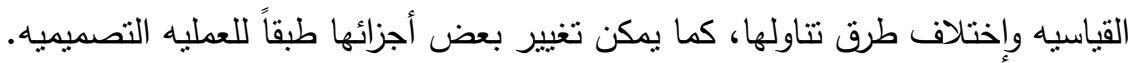


ومن خلال مراحل العمل السابق ذكرها، والإستفاده من عناصر الرصد المختلفه،

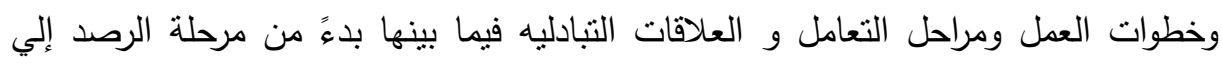
التحليل والتقييم والتطوير والتنفيذ، وهي الخطوات المؤسسيه في المنهج بالإضافه إلي الخطوات الإجرائيه الأخري.

\section{المنتائية والميوكيامت}

أولاً: النتائج:

1- التتمية المستدامة هي نتاج جهود المجتمع بأكمله، عبر خطوط شمولية طويلة الأمد، نحو تحقيق وتطوير

$$
\text { مجتمع متوازن وفق سياسات بيئية وإجتماعية وإقتصادية وسياسية مدروسة. }
$$

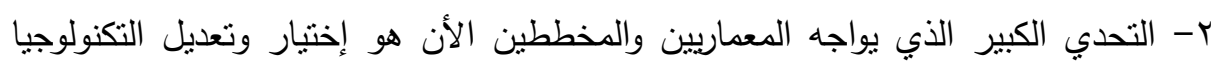

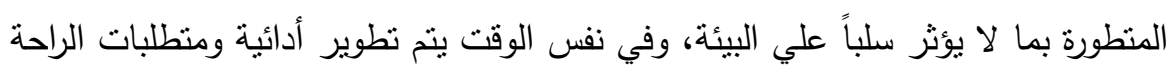
في المسار المتوافق بيئياً.

r- يمكن إستخلاص مجموعة من المبادئ التي إستتد عليها المسار البيئي وتوفير الراحه للمشاه دون التأثثر السلبي علي البيئه والتي يمكن تطويرها كمؤشرات للمسار البيئي

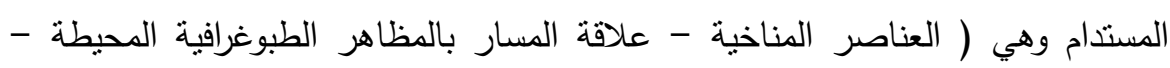
الفراغات المفتوحة والكتل المبنية - الغطاء النباتي وتتسيق الموقع - طبيعة أسطح المسارات - شكل وتوجيه الأسطح العمرانيه - كثافة الحركه ونوعية الأنشطة ).

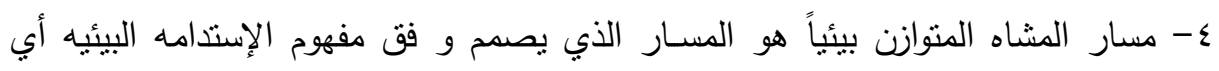
يكون نابعاً من بيئتة ومتوافقاً معها ومستفيداً من إمكانياتها ومحافظً علي مواردها للأجيال

$$
\text { القادمه. }
$$

ه- تشجيع العهـران المستدام وترشيد أساليب إنتاجيته وإستهلاك الطاقه المتوازن هو أحد

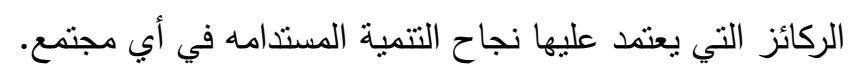

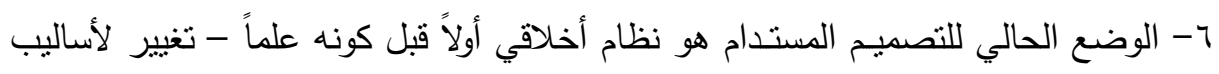
الحياه والإتجاه نحو المحسافظة علي البيئات المحليه والعالميه، فتطور الأسس المعرفيه العلميـه يزود المهارات والأساليب وطرق التنفيذ لتحقيق أهداف التخطيط والتصميم البيئي.

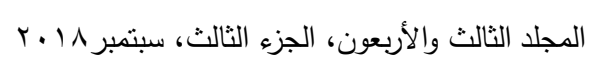


V- نجد أن التعامل مع مسارات المشاه البيئيه المستدامه له العديد من النتائج الإيجابية الهامة والتي منها التعرف علي طرق تحقيق الفراغات الصديقة للمشاة ونوفير مناطق مرنه في

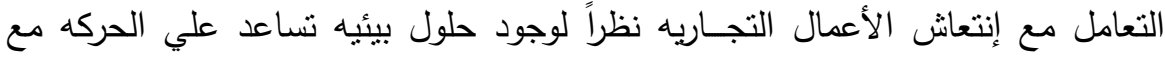

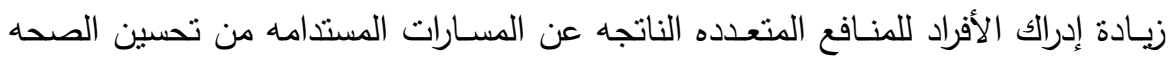
والبيئه وسهولة الوصول مع سهولة إستخدام الثوارع بصفه عامة والثعور بالراحه والأمـان، ومن أهم الإيجـابيات التي قد شملت الأفراد بصفة عامة مشاركتهم في إتخاذ إنهاذ القرارات الخاصه بالتصميم، مع تحويل السلوك نحو المسارات علي مبادئ التسويق الإجتماعي والإقتصادي مع الترويج للصحه والبيئة.

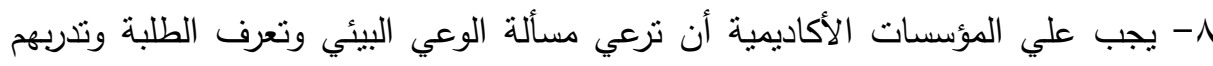
علي أخلاقيات التصميم البيئي وتطوير مهاراتهم وأساسهم المعرفي في التصميم البيئي المستدام.

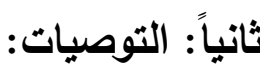
1- نوصي المعماريين أن يعملوا علي القضايا البيئية أثناء تدريبهم وممارستهم العمليه

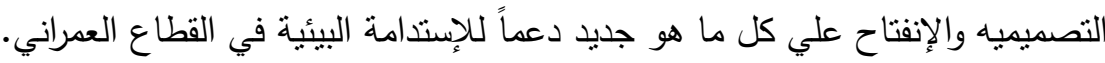

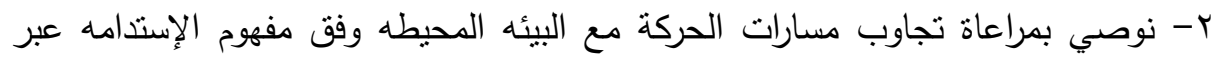

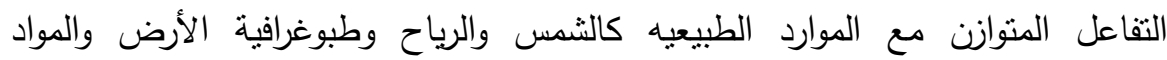
المستخدمه المنوفرة. r- نوصي بمراعاة إستخدام التكنولوجيا المتوافقة مع البيئة لتحقيق الراحة الحرارية للفراغات الخارجية خاصة مسارات المشاة . ع- نوصي بإتباع المعايير الإرشادية التالية في مرحلة التصميم و تقييم المشروعات المقدمة قبل التتفيذ: أن تكون المسارات مباشرة ومستمرة بقدر الإمكان مع تجنب الميول الثديدة فيها وكذلك الإقلال من إستخدام السلالم العالية لتسهيل حركة كبار السن والمعاقين. 
أن تكون مسارات المشاة شبكة متصلة كذلك بالنسبة للاراجات مع تخصيص حارة خاصة لها وأماكن لإنتظار الدراجات.

• أن تكون المسارات آمنة ومراقبة من قبل المباني المطلة عليها.

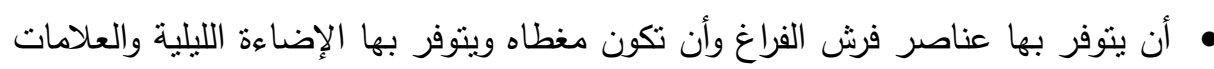
الإرشادية، وبها علامات مميزة لتعزيز الهوية المحلية.

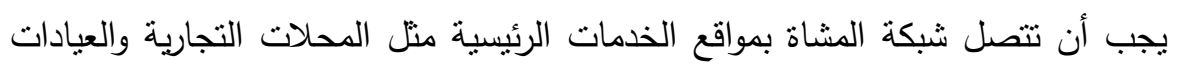

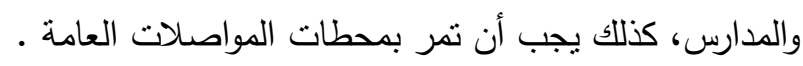

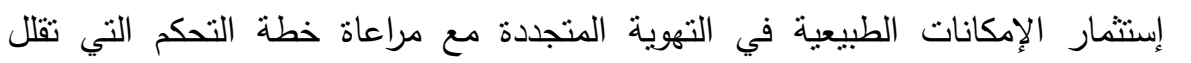
إستخدام الطاقة وتحقق الراحة القصوي.

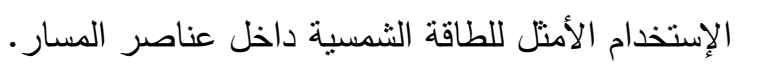
• • ضمان أن أنظمة الإدارة صديقة للبيئة وللمستخدم وغير معقدة. • تحقيق الفرص المناسبة لتوليد الطاقة الكهربائية المتجددة والمجمعة بموقع المسار . • • إستخدام النظم السليمة لتوفير المياه المستخدمة في عناصر تتسيق الموقع.

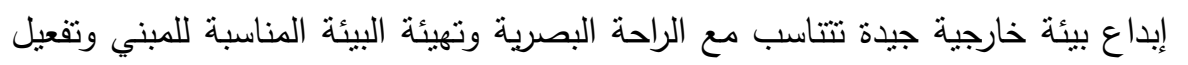
إستخدام الصفات النباتية المتميزة ( الأثجار الغير دائمة الخضرة مثنلاً ) و الصفات البهات البيئية والتي يمكن إستخدامها في تحقيق الراحة الحرارية.

\section{المرالئar}

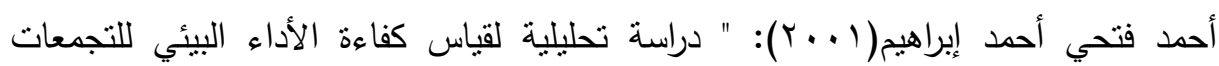

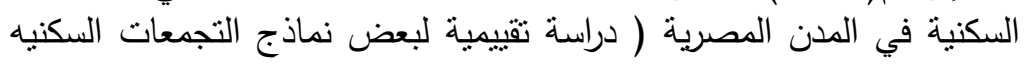

بمصر ) "، ماجستير ، كلية الهندسه، جامعة القاهره.

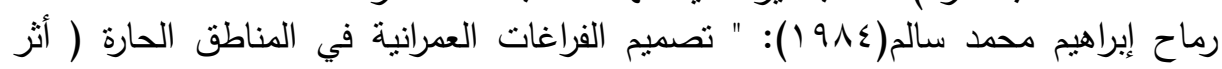

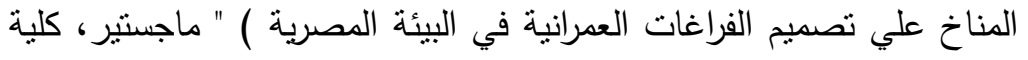
الهندسه، جامعة القاهره.

زينب فيصل(r . . r): " التميز في مسارات الحركة "، ماجيستير، كلية الهندسه، جامعة

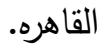


هينار أبو المجد( ع . . ؟): " تصميم الفراغات العمرانية لتحقيق الراحة الحرارية "، ماجسنير،

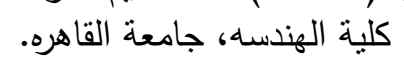

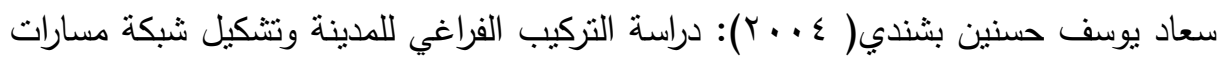

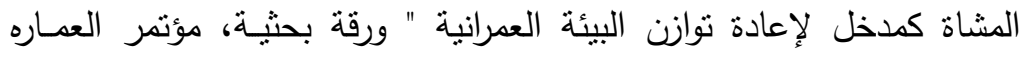

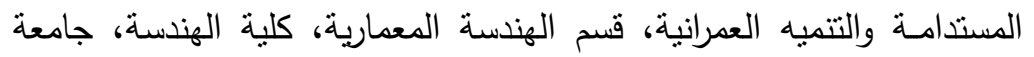

عمر الحسيني (991 ()): " تأثثر عناصر الحركة علي التتمية المستدامة " بحث منشور، مجلة المهندسين المصريه، القاهره

Chiras,D. \& Wann , D. (2005): Superbia! 31 Ways to Create Sustainable Neighborhoods. Canada : New Society Publishers.pp,68-112.

Hasna,A.(2008): “A review of sustainability assessment method in engineering"The international journal of environmental,cultural,economic and social sustainability,Melburne, available on line at www.sustainability- journal.compp1-15

Jianguo,W. (2010):."Urban sustainability an inevitable goal of landscape research". landscape ecol 25 ,SpringerSciense + Business media B.V.pp 1-4.

Peterson,S.C.(1996):." Sustainability and the urban landscape : an introduction of a qualitative assessment tool for understanding and enhancing sustainability in urban open spaces". Unpublished thesis ,Faculty of British Columbia. pp 60-115.

Rubenstein, h.,(1992): “ pedestrian malls, streetscapes, and urban spaces ", Wilmington, Delaware. 


\title{
AN ANALYTICAL STUDY FOR ENVIRONMENTAL SUSTAINABLE INDICATORS IN PEDESTRIAN TRAILS
}

\author{
Abdellhafiz, Nashwa, Y. \\ Department of Architecture at October Higher Institute of Engineering \\ and Technology, 6 Th October, Giza, Egypt
}

\begin{abstract}
Pedestrian trails is considered one of the most important effective elements whether its formation or urban system, so it's the most important tool in achieving sustainability in urban boundary. Its known that environmental sustainability is a main condition to improve the life type. The research makes a suggestion to improve and develop the usage of site elements of pedestrian trails in addition to clarify the relationship between the components and elements of pedestrian trails formation and its ways to achive environmental sustainability as a tool to evaluate environmental performance of the pedestrian trails with clarifying the arrangement of the sustainable design, the elements forming the pedestrian trails in addition to justify a group of relationships between these criteria.
\end{abstract}

Keywords: pedestrian trails indicators - elements forming the environmental systems - elements forming the pedestrian trails. 